\title{
Late Quaternary Deposition in the Inner Basins of the California Continental Borderland- Part A. Santa Monica
}

Scientific Investigations Report 2004-5183 


\section{Late Quaternary Deposition in the Inner Basins of the California Continental Borderland- Part A. Santa Monica Basin}

By William R. Normark and Mary McGann

Scientific Investigations Report 2004-5183 


\section{U.S. Department of the Interior}

Gale A. Norton, Secretary

U.S. Geological Survey

Charles G. Groat, Director

Version 1.0, 2004

This publication is available only online at: http://pubs.usgs.gov/sir/2004/5183/

Text edited by James W. Hendley II

Production and design by Stephen L. Scott

Manuscript approved for publication, September 9, 2004

Any use of trade, product, or firm names in this publication is for descriptive purposes only and does not imply endorsement by the U.S. Government 


\section{Contents}

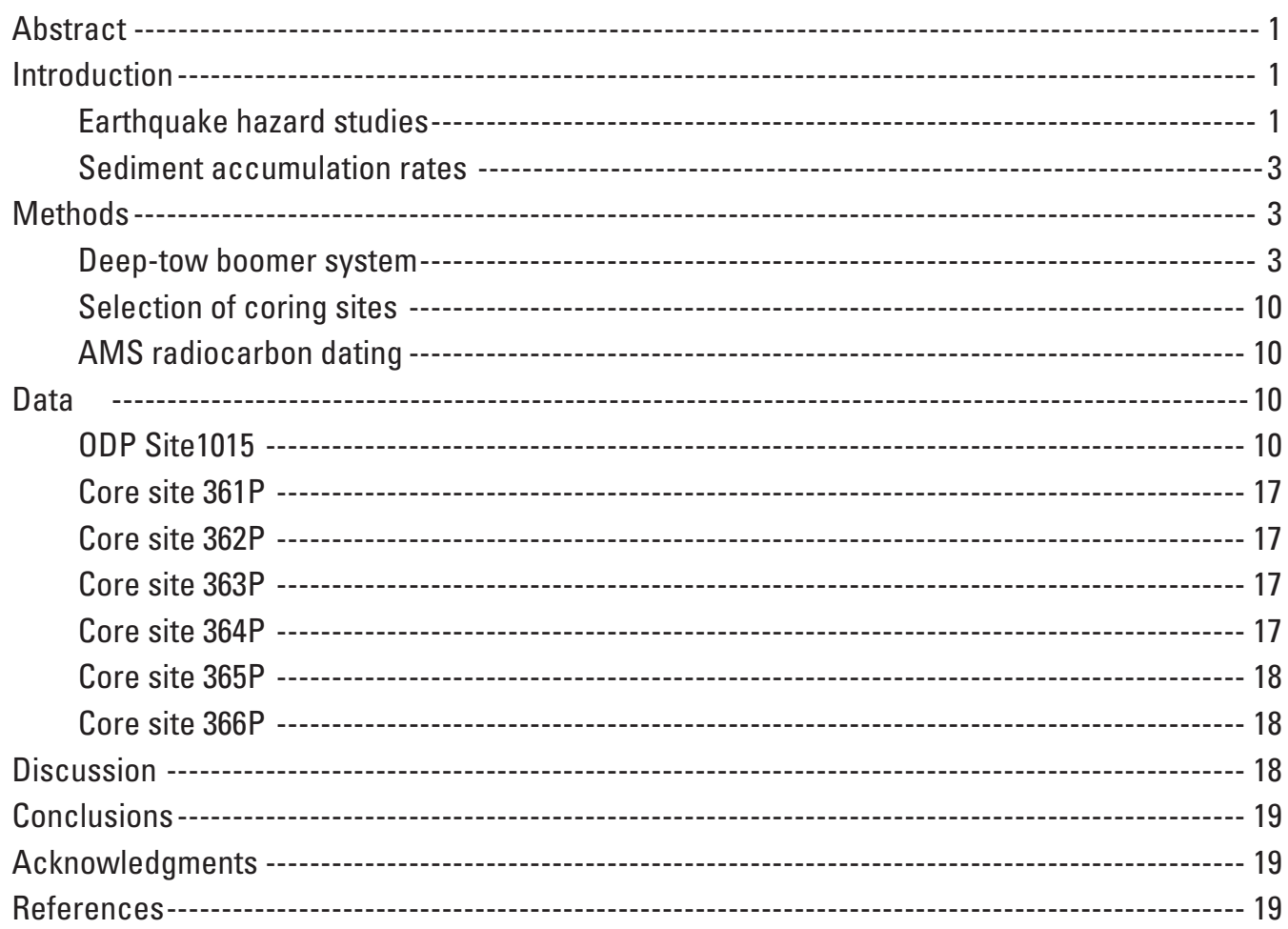

\section{Figures}

1. Bathymetric map of Santa Monica Basin piston core sites and ODP Site

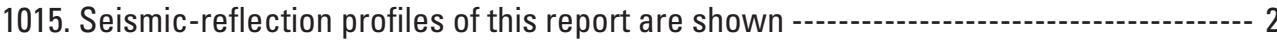

2. Structural interpretation of Santa Monica Basin (modified from Fisher and others (2003) and multibeam shaded relief image of Santa Monica Bay ------------------- 4

3. Single-channel seismic-reflection profiles relative to ODP Site 1015-------------- 5

4. Deep-tow Huntec boomer profiles showing key reflectors for the upper

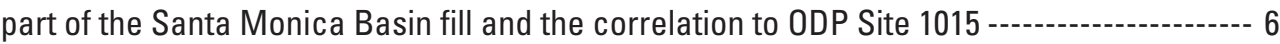

5. Sediment log for ODP Site 1015 - 7

6. Sediment log, core photographic, geologic setting, and geophysical log

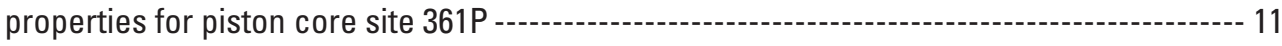

7. Sediment log, core photographic, geologic setting, and geophysical log properties for piston core site 362P

8. Sediment log, core photographic, geologic setting, and geophysical log

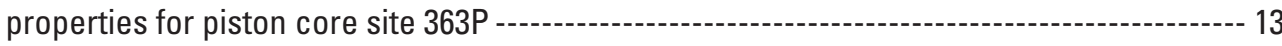

9. Sediment log, core photographic, geologic setting, and geophysical log properties for piston core site 364P

10. Sediment log, core photographic, geologic setting, and geophysical log properties for piston core site 365P

11. Sediment log, core photographic, geologic setting, and geophysical log properties for piston core site 366P

12. Examples of dated fault and landslide movement - 20

\section{Table}

Radiocarbon ages from piston cores and ODP $1015-$ 


\title{
Late Quaternary Deposition in the Inner Basins of the California Continental Borderland- Part A. Santa Monica Basin
}

\author{
By William R. Normark and Mary McGann
}

\section{Abstract}

Radiocarbon dating of sediment core samples from Santa Monica Basin document Holocene (younger than approximately $11 \mathrm{ka}$ ) landslides and fault offsets along the basin margin. The new dates include 17 from six piston cores on the continental slope and 11 from Ocean Drilling Program Site 1015 on the basin floor. The dates, which are based on data from pelagic and benthic foraminifera in addition to several dates from mollusk shells, are used to provide chronostratigraphic control for a previously determined basinwide seismic stratigraphy. The geologic setting at the core sites and a sediment log for each core are shown. In addition, each sediment log is accompanied by a color core photograph as well as P-wave velocity and gamma-ray density profiles. The primary purpose of the report is to make the radiocarbon dates available for other studies in the Santa Monica Basin. A comparison of sediment accumulation rates between the late Pleistocene and Holocene provides insight to the effects of sea-level change on sediment input to the basin. In addition, the results can be used to evaluate the effectiveness of wire-line piston coring in providing age control for earthquake hazard and sedimentologic studies.

\section{Introduction}

In recent years, the Santa Monica Bay has been the focus of intensive sampling programs in support of studies that dealt with sediment sources, sediment distribution patterns, and transport processes, particularly in regard to pollutant issues (see for example, Lee and Weisberg, 2003). Beginning in 1998, a series of sediment coring efforts beginning in the Santa Monica Basin focused on the deeper water areas of the inner basins of the California Borderland. The primary intent of the deeper water work was to determine sediment accumulation rates along the basin margins in order to provide age control for active faults and recent submarine landslides. Radiocarbon dating of U.S. Geological Survey (USGS) piston cores was combined with dating of the core recovered at ODP Site 1015 (Shipboard Scientific Party, 1997). The sedimentation rate data show limited effects of sea level change on sediment supply to the basin, compared to the effect on sedimentation rates on the adjacent shelf and slope of Santa Monica Bay reported by and Lee (2004).

\section{Earthquake hazard studies}

The focus of the southern California earthquake-hazard task is to identify the nature of threats from landslides, earthquakes, and tsunamis in the offshore southern California coastal region. To meet this objective, it is necessary to determine the style and timing of active (Holocene) deformation within the basins and slope areas adjacent to the highly populated urban corridor from Santa Barbara to San Diego. Highresolution seismic-refection profiles are used to determine the sites for sediment-core samples that can be used to date fault offsets, active folding, and submarine landslides. This report is the first in a series that will describe the geological setting of the sample localities, the sedimentological and geophysical log properties of the core samples, the radiocarbon ages of the sediment recovered, and the resulting implications for dating of tectonic activity.

The study area for this report is the Santa Monica Basin west of Los Angeles (fig. 1). This northwest-southeast trending basin, which has a maximum water depth approaching 1,000 $\mathrm{m}$, subsided during the Pliocene and Quaternary in a predominantly strike-slip tectonic regime (Crouch and Suppe, 1993; Sorlien and others, 2003). Except to the southeast, where the Santa Monica Basin is separated from San Pedro Basin by bedrock of the Redondo Knoll, the basin is bounded by a complex arrangement of strike slip, reverse, and buried thrust faults (see for example, Nardin and Henyey, 1978; Sorlien, 1999, Dolan and others, 2000; Sorlien and others, 2003; Fisher and others, 2003). During the latest Quaternary, the Santa Monica Basin has been filling with sediment at accumulation rates as much as $3 \mathrm{~m} / \mathrm{ka}$ (Shipboard Scientific Party, 1997). Dume and Santa Monica canyons provide modest sediment to low-relief submarine fans at the base of the slope, but the dominant source of sediment is the Hueneme Canyon at the western end of the basin (fig. 1; Normark and others, 1998; Piper and others, 1999; Piper and Normark, 2001). Hueneme Canyon cuts across the shelf and receives much of the coarse sediment delivered to the coast from the Santa Clara River, from which hyperpycnal flows deliver sediment directly to the canyon and adjacent basin slope (Warrick and Milliman, 2003).

Normark and Piper (1998) provided a preliminary assessment of Holocene deformation along the margins of the Santa Monica Basin. High-resolution seismic-reflection data collected by the Geological Survey of Canada (GSC; see 


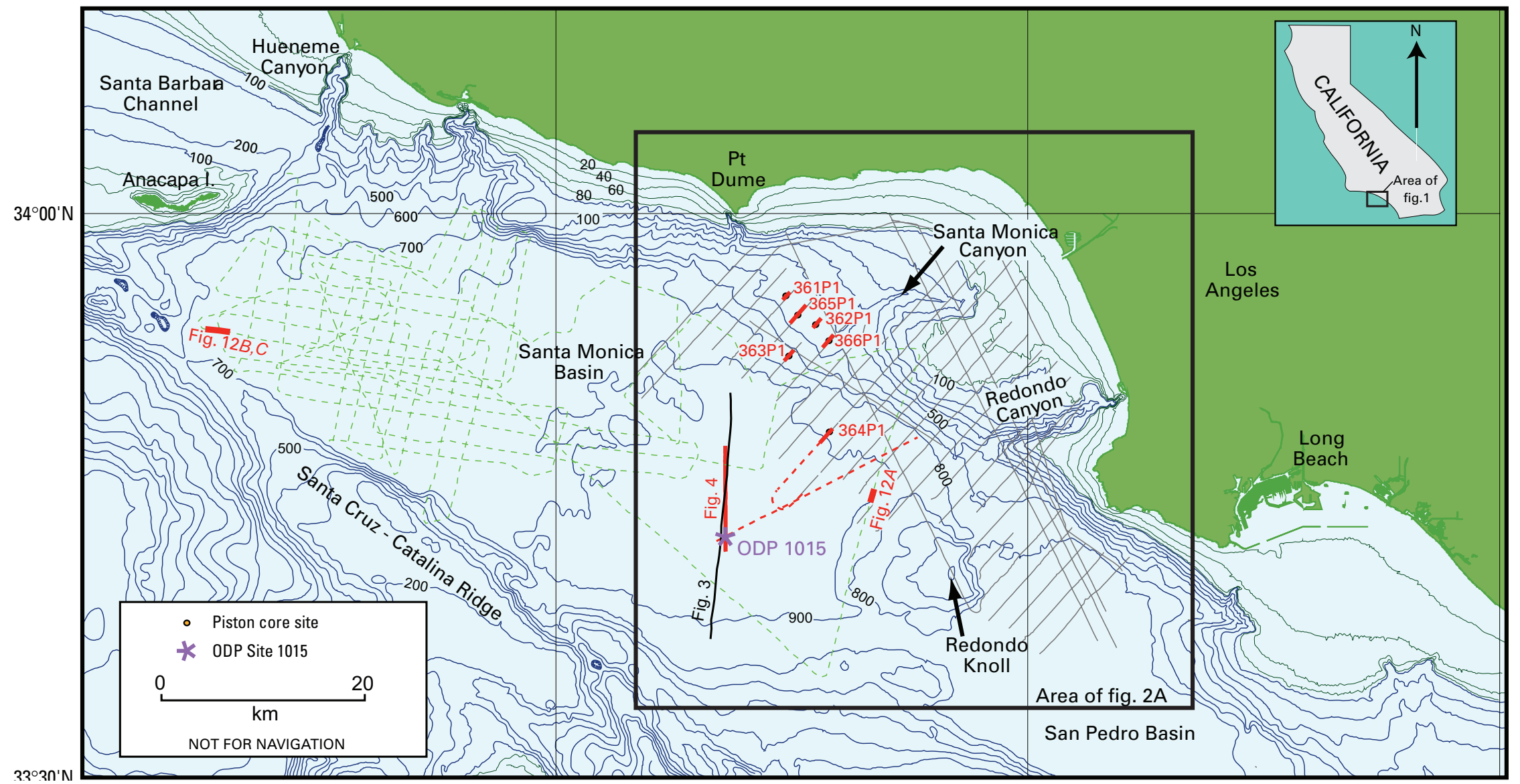

Figure 1. Bathymetric map of Santa Monica Basin showing position of cores used in this study (ODP Site 1015 and piston cores $361 \mathrm{P} 1$ through $366 \mathrm{P} 1$ ). Thin green, dashed lines show tracklines for Geological Survey of Canada (GSC) cruise 91-062. Thin dark gray lines show tracklines for deep-tow boomer profiles collected during U.S. Geological Survey cruises A-1-98-SC and 0-1-99-SC in support of earthquake hazard assessment for offshore southern California. Locations of the seismic-reflection profiles in the vicinity of ODP Site 1015 presented in figures 3 and 4 are shown as heavy solid lines in black and red, respectively. Locations of deep-tow boomer lines used to correlate the high-resolution stratigraphic framework (Normark and others, 1998; Piper and others, 1999) with ODP 1015 and piston-core site 364P1 are shown as thin, red dashed lines. Thick red lines through the piston core sites give length of boomer profiles illustrated in figures 6 through 11. Thick red lines near northwest and southeast ends of the basin show seismic-reflection profiles of figure 12. Rectangle with thick lines shows location of figure $2 A$. Bathymetric contours in meters with 20-m-interval on shelf and 100-m-interval for deeper water (adapted from NOAA, 1998). 
tracklines in fig. 1) were interpreted using the depth to the Pleistocene-Holocene boundary from the initial results from Ocean Drilling Program (ODP) Site1015 (Shipboard Scientific Party, 1997). Preliminary results on the timing and recurrence of deformation in Santa Monica Basin showed that during the last $5 \mathrm{ka}$ the western end of the basin is actively deforming with multiple deformational events (folding, tilting, fault offsets). Within the last $10 \mathrm{ka}$, large submarine slides have occurred, primarily south and west of Santa Monica Bay. During the last $2 \mathrm{ka}$, the northeast margin of the basin has many faults that offset the seafloor and that have been active (Normark and Piper, 1998).

The main effort of the ongoing evaluation of seismic hazard in Santa Monica Basin has been to map active structures that lie within 40 to $50 \mathrm{~km}$ of the shore (see USGS tracklines in fig. 1). Fisher and others (2003) demonstrated that the northeastern margin of the basin shows different degrees of deformation north and south of Santa Monica Canyon (fig. 2A). Northwest of this canyon, two shallow anticlines on the lower slope extend toward Point Dume and are cored by faults showing reverse or thrust separation. Southeast of Santa Monica Canyon, the lower-slope sediment is deformed by a complex arrangement of strike-slip, normal, and reverse faults along the San Pedro Escarpment that locally form flower structures (Normark and Piper, 1998; Fisher and others, 2003). These faults merge downward with the San Pedro Basin Fault Zone (fig. $2 A$ ), which is nearly vertical and strike-slip (Fisher and others, 2003).

\section{Sediment accumulation rates}

The high-resolution seismic-reflection data from the GSC provided a basis for establishing a detailed stratigraphic framework for sediment of late Quaternary age in the deep Santa Monica Basin (Normark and others, 1998; Piper and others, 1999; Piper and Normark, 2001). These studies identified about 15 key reflectors, many of which can be recognized across the basin floor and lower basin slopes. Some of these reflectors are shown in figures 3 and 4 where they have been further mapped using other reflection profiles collected by the USGS during 1998 (fig. 1). The GSC data did not directly intersect ODP Site 1015 (fig. 1), but the USGS data collected in 1998 did cross the drill site. Thus, the key reflectors can now be correlated with confidence to Site 1015 (figs. 4 and 5; Shipboard Scientific Party, 1997).

Site 1015 was not studied in detail for the ODP Scientific Results volume for Leg 167 and, to date, only a few unpublished radiocarbon ages have been available to evaluate deformation in Santa Monica Basin. The unpublished dates confirmed the shipboard evaluation that the Holocene deposits are nearly 30 meters thick, which is much greater than previous estimates (Shipboard Scientific Party, 1997). The Santa Monica Basin is a closed basin and makes an ideal subject for a source-to-sink evaluation of the effects of sea level on sediment supply to the deep basin floor. In addition, deep- tow boomer data have been used to show that the uppermost key reflectors can be traced from ODP Site 1015 to about 40 $\mathrm{m}$ above the basin floor. This suggests that turbidity currents from the Hueneme Canyon are thick enough to deposit sediment well above the basin floor (Piper and others, 2003).

To make further use of the ODP core data for both stratigraphic studies and seismic hazard evaluation, this report documents a comprehensive suite of radiocarbon ages for sediment from cores in Santa Monica Basin that can be used to refine initial efforts to determine the deformation history within the basin (see for example, Normark and Piper, 1998; Fisher and others, 2003). This study is based on data from ODP Site 1015 in addition to site-specific piston cores along the basin margin (table 1 and fig. $2 B$ ). Chronostratigraphic control for the basin-wide, high-resolution seismic stratigraphy developed for Santa Monica Basin can be used to date faulting and mass-wasted deposits within the basin floor and base-of-slope areas. Short piston cores from the northeastern flank of the basin were intended to provide age control for folding and faulting on the mid-slope area. The dated sediment cores are also used to evaluate sedimentation rates during the change from glacial sea-level lowstand to the present highstand.

\section{Methods}

The Santa Monica Basin receives sediment from at least four submarine canyons that are fed directly from rivers or from sand being transported in the littoral zone (fig. 1; Normark and others, 1998). For this reason, deposits in the basin are relatively sand rich (see for example, fig. 5). To develop a fine-scale seismic stratigraphy and to image active faults that offset the sea floor or strata close to the sea floor, a deep-tow boomer system was chosen to obtain the necessary vertical resolution of bedding and yet still be capable of imaging sandy deposits that are tens of meters thick. We used boomer reflection profiles to select specific core sites adjacent to fault and fold structures and then used microfossil carbonate tests for radiocarbon dating to date recent displacements.

\section{Deep-tow boomer system}

The high-resolution Huntec DTS boomer system is well suited for reflection profiling studies in basins of the California Borderland. The DTS boomer source is towed between $50 \mathrm{~m}$ and $160 \mathrm{~m}$ below the sea surface (depending upon the water depth) and can image the upper few tens of milliseconds of strata with a resolution of better than $0.5 \mathrm{~ms}(0.4 \mathrm{~m})$. Power output is 350 Joules, with a firing rate that is dependent on water depth, ranging from $0.75 \mathrm{sec}$ to $1.25 \mathrm{sec}$ with the longer interval over the deeper water parts of the basin. For the profiles obtained in support of the Santa Monica Basin study, the receiver was a 5-m-long Benthos 10-element hydrophone array towed from the same fish that houses the boomer source. 


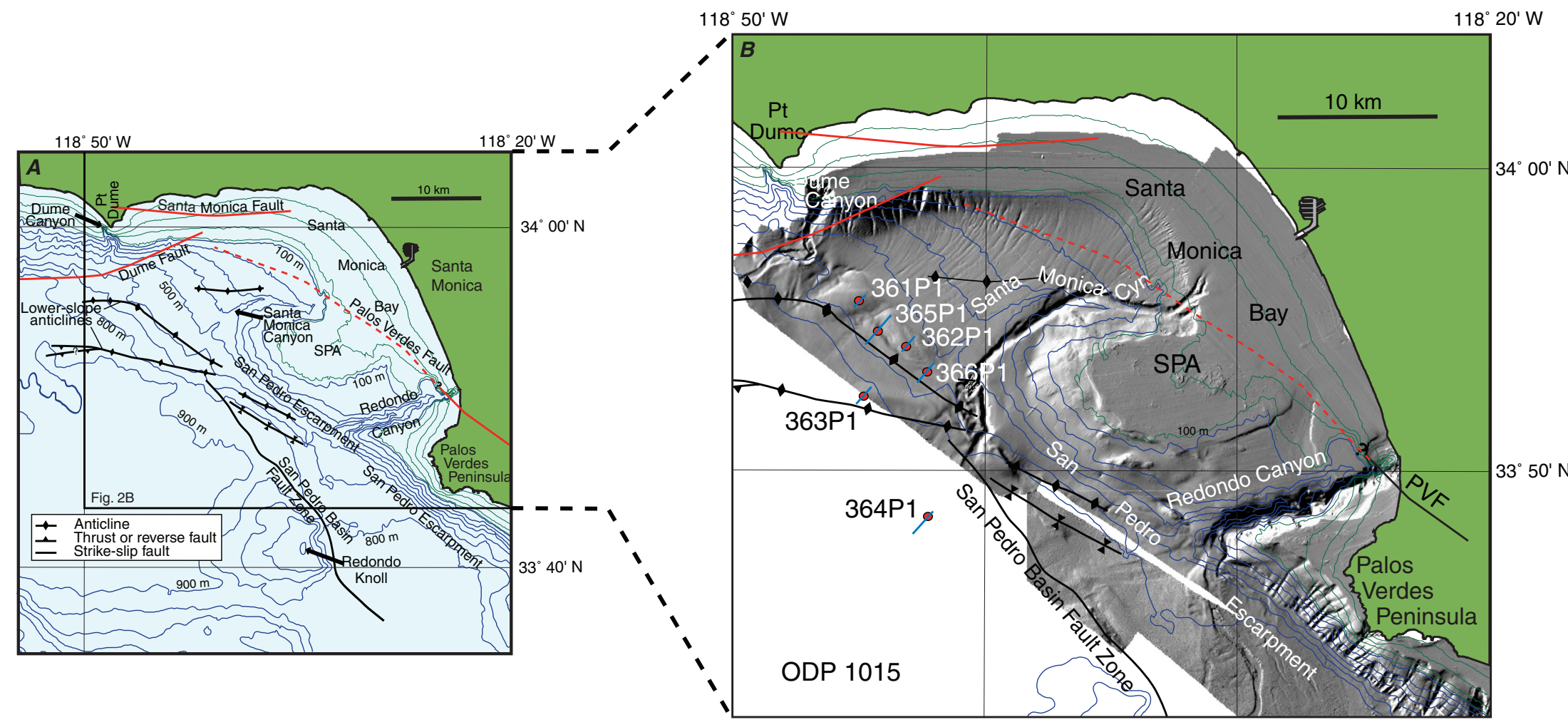

Figure 2. A, Summary of primary structural features (shown in black) along the northeastern margin of Santa Monica Basin as established by Fisher and others (2003). Features shown in red are schematic representation of other faults in the area (see references for figure 1 in Fisher and others, 2003). The extension of the Palos Verdes Fault (PVF) remains conjectural north of Redondo Canyon and is shown as a dashed red line. SPA is shelf projection anticlinorium. See figure 1 for location. $B$, Shadedrelief map of the shelf and basin slope east of Santa Monica Basin based on multibeam bathymetric data; view is from directly overhead with illumination from the northwest (Gardner and Dartnell, 2002). The fault and fold patterns are the same as for figure 2A. Piston core locations are shown together with tracklines for deep-tow reflection-profile segments of figures 6 thorugh 11 (see figure 1 for explanation). 


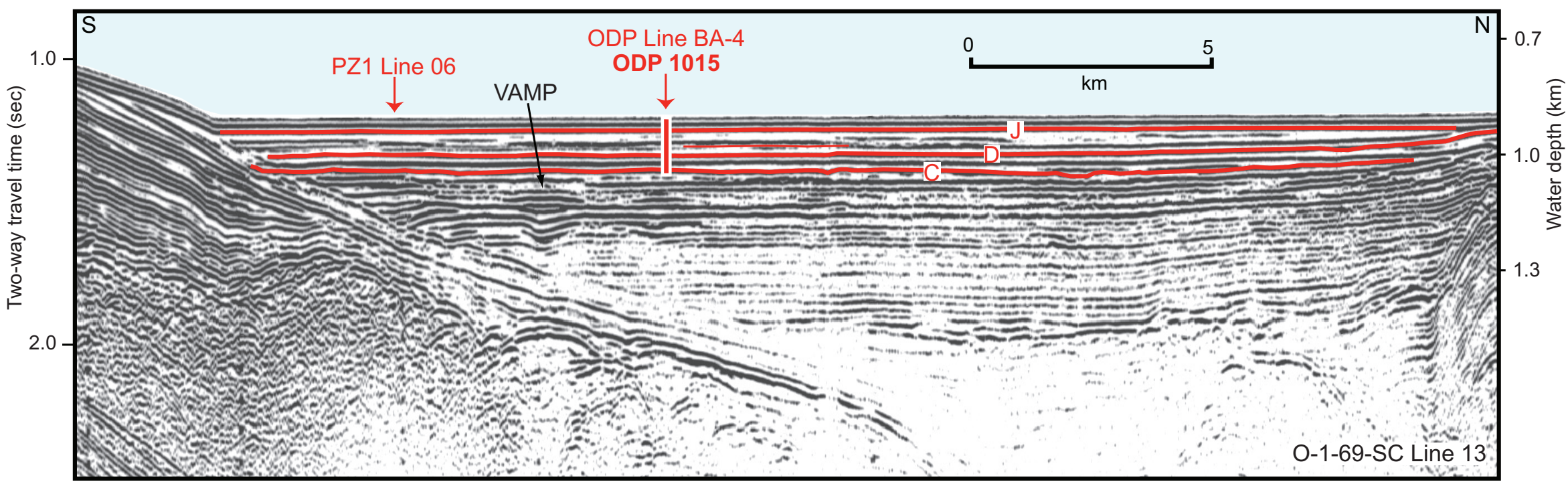

Figure 3. Seismic-reflection profile showing basin-floor stratigraphy of Santa Monica Basin sediment at ODP Site 1015. Line 13 from U.S. Geological Survey cruise 0-1-69-SC. Key basin-wide stratigraphic reflectors $\mathrm{C}, \mathrm{D}$, and $\mathrm{J}$ are shown in this profile, which was obtained with a single-channel sparker sound source; refer to figure 4 for reflectors between $\mathrm{J}$ and the seafloor and see text for explanation. Profile location is shown in figure 1 . This profile shows evidence for gas accumulation in the sediment below about 0.25 sec two-way travel time, which is just a few tens of meters deeper than the bottom of ODP Hole 1015A at $149.5 \mathrm{mbsf}$; see, for example, high-amplitude (bright) reflections locally with a Velocity-AMPlitude (vamp) -like structure south of the ODP drill site (see Scholl and Cooper, 1978). 


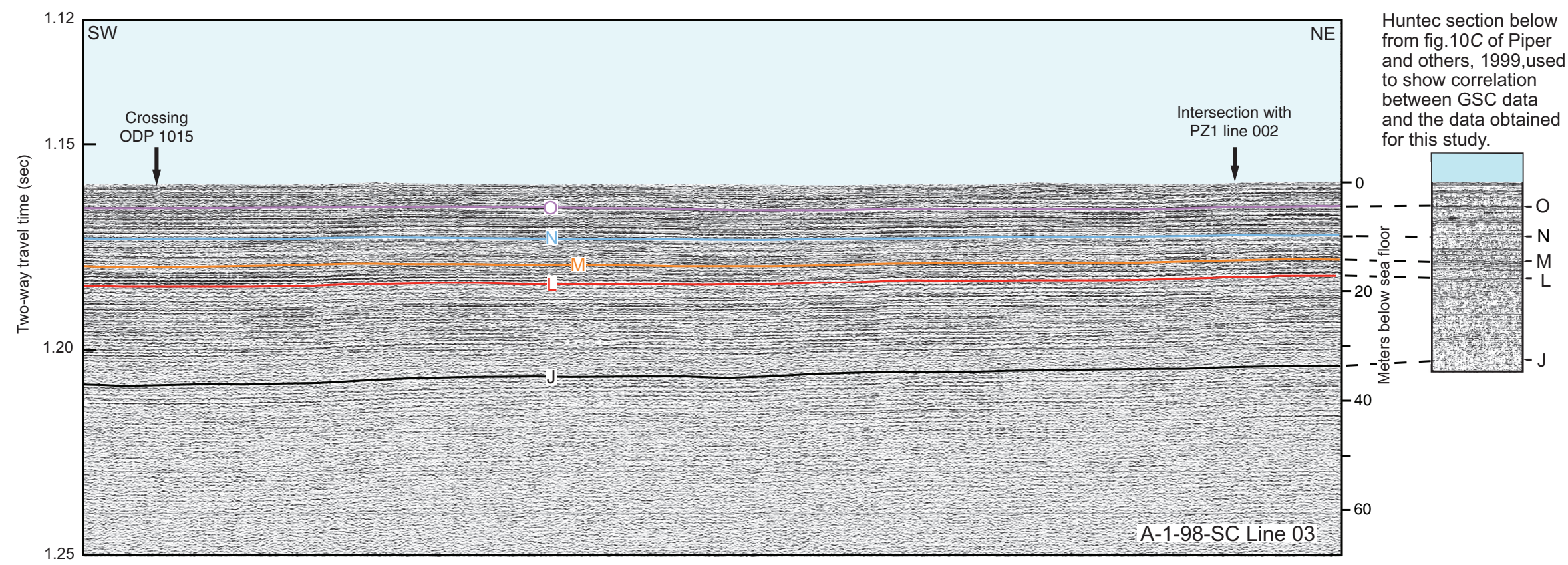

Figure 4. High-resolution deep-tow boomer profile that passes through ODP Site 1015 and intersects Line 2 from Geological Survey of Canada (GSC) cruise 91-062. See figure 1 for location. Reflectors 0 to $\mathrm{J}$ are regional reflectors that can be correlated throughout much of the Santa Monica Basin using the GSC survey of the western end of the basin (Piper and others, 1999) and the U.S. Geological Survey data farther east (see fig. 1). 


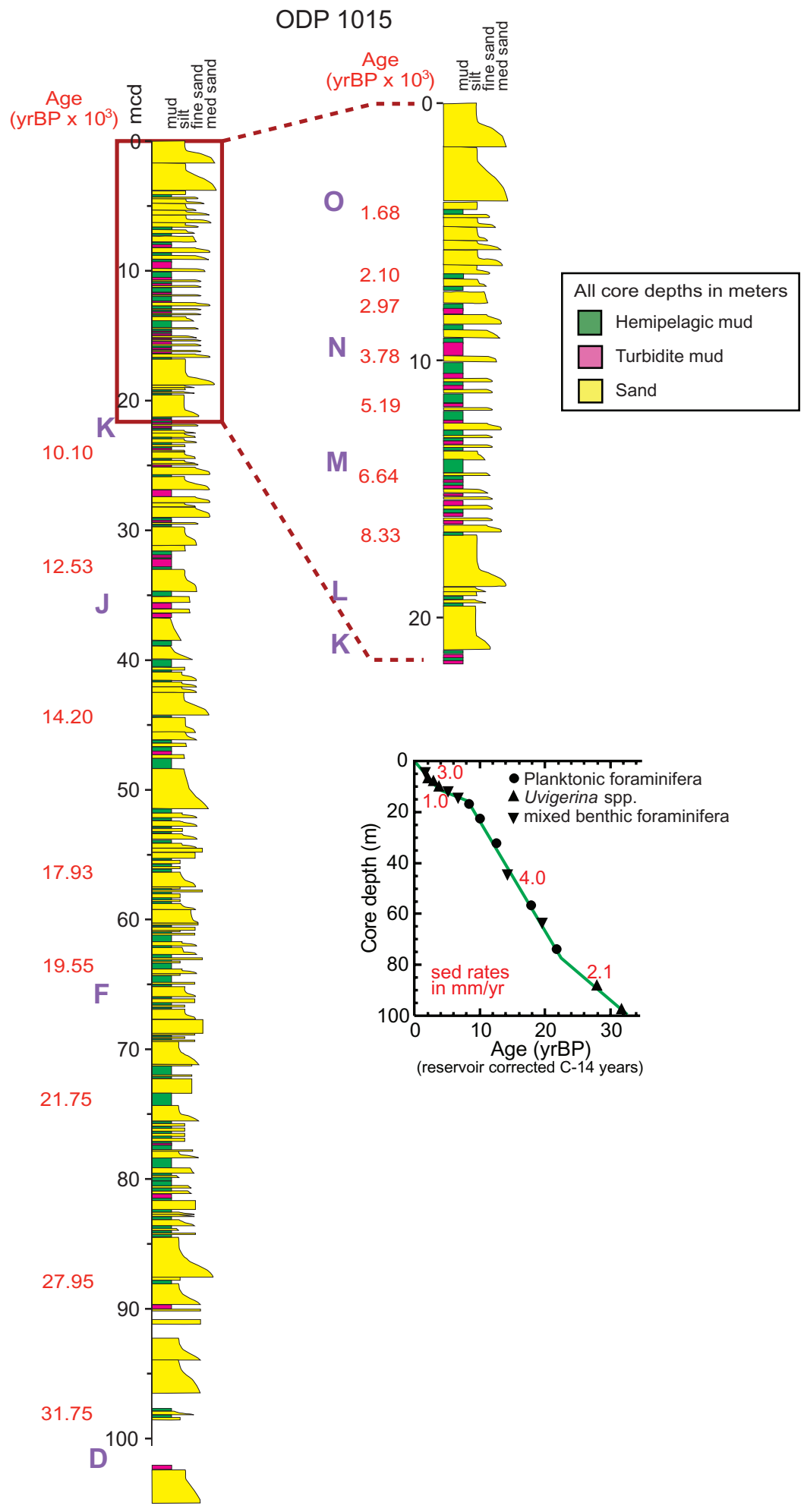

Figure 5. Graphical sediment log for ODP Site 1015 constructed from the Visual Core Descriptions (VCDs) obtained from the Ocean Drilling Program archive at Texas A\&M University. The log is constructed combining the VCDs from Holes 1015A and $1015 \mathrm{~B}$ in order to avoid disturbed sections wherever possible; thus, the vertical scale ( $\mathrm{mcd}=$ meters core depth) reflects the combined logs. Radiocarbon dates are shown in red to the left of the sediment logs. The upper $20 \mathrm{~m}$ of the log is expanded (at the right) to better illustrate the relation between the radiocarbon dates and the late Holocene interval of key reflector stratigraphy. The graph at lower right shows the sediment accumulation rate in $\mathrm{mm} / \mathrm{yr}$. Location of Site 1015 in figures 1 and 2B. 
Table 1. Radiocarbon ages from piston cores and ODP 1015 from Santa Monica Basin.

\begin{tabular}{|c|c|c|c|c|c|c|c|c|}
\hline $\begin{array}{c}\text { NOSAMS } \\
\text { Accession } \\
\text { Number }\end{array}$ & Core, section, depth & $\begin{array}{l}\text { Meters below } \\
\text { sea floor } \\
\text { (mbsf) }\end{array}$ & $\begin{array}{l}\text { Description } \\
\text { of dated } \\
\text { material }\end{array}$ & d13C & $\begin{array}{c}{ }^{14} \mathrm{C} \\
\text { Age } \\
\text { (yr B.P. })\end{array}$ & $\begin{array}{c}\text { Reservoir } \\
\text { Age } \\
(\mathbf{y r})^{1}\end{array}$ & $\begin{array}{c}\text { Corrected } \\
\text { Age } \\
(\text { yr B.P. })^{1}\end{array}$ & $\begin{array}{c}\text { Calendar } \\
\text { Age } \\
(\text { yr B.P. })^{2}\end{array}$ \\
\hline OS-40035 & A2-98-SC 361P1, sec. $1,40-44 \mathrm{~cm}$ & $0.40-0.44$ & $\begin{array}{l}\begin{array}{c}\text { Gyroidina altiforms } \\
\text { (benthic) }\end{array} \\
\end{array}$ & -1.01 & $14,800 \pm 75$ & 1,750 & $13,050 \pm 75$ & $15,580 \pm 75$ \\
\hline OS-36191 & A2-98-SC 361P1, sec. $2,36-37 \mathrm{~cm}$ & $0.80-0.81$ & Mollusk & 0.76 & $15,150 \pm 70$ & 1,750 & $13,400 \pm 70$ & $15,990 \pm 70$ \\
\hline OS-40036 & A2-98-SC 361P1, sec. 2, 75-77 cm & $1.19-1.21$ & Cibicides sp. (benthic) & -0.41 & $17,950 \pm 95$ & 1,750 & $16,200 \pm 95$ & $19,210 \pm 95$ \\
\hline OS-40037 & A2-98-SC 361P1, sec. 2, 140-142 cm & $1.84-1.86$ & Cibicides sp. (benthic) & -0.39 & $19,150 \pm 110$ & 1,750 & $17,400 \pm 110$ & $20,590 \pm 110$ \\
\hline OS-40038 & A2-98-SC 362P1, sec. $2,80-82 \mathrm{~cm}$ & $1.77-1.79$ & Uvigerina spp. (benthic) & -1.41 & $13,050 \pm 55$ & 1,750 & $11,300 \pm 55$ & $13,160 \pm 55$ \\
\hline OS-39100 & A2-98-SC 362P1, sec. 2, 133-135 cm & $2.30-2.32$ & Mixed benthics & -0.98 & $13,000 \pm 65$ & 1,750 & $11,250 \pm 65$ & $13,150 \pm 65$ \\
\hline OS-40039 & A2-98-SC 363P1, sec. $2,60-62 \mathrm{~cm}$ & $1.12-1.14$ & Uvigerina spp. (benthic) & -1.23 & $13,650 \pm 65$ & 1,750 & $11,900 \pm 65$ & $13,820 \pm 65$ \\
\hline OS-40066 & A2-98-SC 363P1, sec. 3, 104-106 cm & $3.05-3.07$ & Mixed benthics & -1.75 & $25,400 \pm 210$ & 1,750 & $23,650 \pm 210$ & \\
\hline OS-40067 & A2-98-SC 363P1, sec. $4,30-32 \mathrm{~cm}$ & $3.65-3.67$ & Uvigerina peregrina (benthic) & -1.09 & $28,200 \pm 280$ & 1,750 & $26,450 \pm 280$ & \\
\hline OS-35616 & A2-99-SC 363P1, sec 4, 123-125 cm & $4.58-4.60$ & Mixed planktics & -1.82 & $29,200 \pm 150$ & 1,100 & $28,100 \pm 150$ & \\
\hline OS-40068 & A2-98-SC 364P1, sec 1, 105-107 cm & $1.05-1.07$ & Uvigerina sp. (benthic) & -0.37 & $4,640 \pm 35$ & 1,750 & $2,890 \pm 35$ & $3,136 \pm 35$ \\
\hline OS-40069 & A2-98-SC 364P1, sec. 3, 28-30 cm & $3.04-3.06$ & Mixed benthics & -1.8 & $9,840 \pm 55$ & 1,750 & $8,090 \pm 55$ & $8,960 \pm 55$ \\
\hline OS-35615 & A2-98-SC-364P1, sec 3, 143-145 cm & $4.19-4.21$ & $\begin{array}{c}\text { Neogloboquadrina } \\
\text { pachyderma }\end{array}$ & 0.12 & $10,600 \pm 75$ & 800 & $9,800 \pm 75$ & $11,130 \pm 75$ \\
\hline OS-40070 & A2-98-SC 365P1, sec. $2,80-82 \mathrm{~cm}$ & $1.39-1.41$ & Uvigerina spp. (benthic) & -3.09 & $>52,000$ & & & \\
\hline OS-40071 & A2-98-SC 365P1, sec. $2,100-102 \mathrm{~cm}$ & $1.59-1.61$ & Uvigerina peregrina (benthic) & -0.8 & Too old to date & & & \\
\hline OS-39101 & A2-98-SC 365P1, sec. $2,140-142 \mathrm{~cm}$ & $1.99-2.01$ & Mixed benthics & -2.38 & $>54,000$ & & & \\
\hline OS-40072 & A2-98-SC 366P1, sec. $1,20-22 \mathrm{~cm}$ & $0.20-0.22$ & Mixed benthics & -1.01 & $7,990 \pm 40$ & 1,750 & $6,240 \pm 40$ & $7,182 \pm 40$ \\
\hline
\end{tabular}


Table 1. Radiocarbon ages from piston cores and ODP 1015 from Santa Monica Basin.—Continued

\begin{tabular}{|c|c|c|c|c|c|c|c|c|}
\hline $\begin{array}{c}\text { NOSAMS } \\
\text { Accession } \\
\text { Number }\end{array}$ & Core, section, depth & $\begin{array}{l}\text { Meters below } \\
\text { sea floor } \\
\text { (mcd) }\end{array}$ & $\begin{array}{l}\text { Description } \\
\text { of dated } \\
\text { material }\end{array}$ & d13C & $\begin{array}{c}{ }^{14} \mathrm{C} \\
\text { Age } \\
\text { (yr B.P. })\end{array}$ & $\begin{array}{c}\text { Reservoir } \\
\text { Age } \\
(\mathbf{y r})^{1}\end{array}$ & $\begin{array}{c}\text { Corrected } \\
\text { Age } \\
(\mathbf{y r} \text { B.P. })^{1}\end{array}$ & $\begin{array}{c}\text { Calendar } \\
\text { Age } \\
(\mathbf{y r} \text { B.P. })^{2}\end{array}$ \\
\hline OS-35811 & ODP 1015B, 002H 02W, 55-57 cm & 4.35 & Mixed benthics & & $3,430 \pm 45$ & 1,750 & $1,680 \pm 45$ & $1,664 \pm 45$ \\
\hline OS-35835 & ODP 1015B, 002H 03W, 144-146 cm & 6.74 & Uvigerina sp. & & $3,850 \pm 40$ & 1,750 & $2,100 \pm 40$ & $2,143 \pm 40$ \\
\hline OS-35836 & ODP 1015B, 002H 04W, 101-103 cm & 7.81 & Uvigerina $\mathrm{sp}$. & & $4,720 \pm 30$ & 1,750 & $2,970 \pm 30$ & $3,238 \pm 30$ \\
\hline OS-35837 & ODP 1015B, 002H 06W, 12-14 cm & 9.92 & Uvigerina sp. & & $5,530 \pm 35$ & 1,750 & $3,780 \pm 35$ & $4,249 \pm 35$ \\
\hline OS-39187 & ODP 1015B, 002H, 07W, 55-57cm & $\sim 11.68$ & Mixed benthics & 0.65 & $6,940 \pm 70$ & 1,750 & $5,190 \pm 70$ & $5,950 \pm 70$ \\
\hline OS-39188 & ODP 1015B, 003H, 02W,119-121cm & 14.50 & Mixed benthics & 1.2 & $8,390 \pm 45$ & 1,750 & $6,640 \pm 45$ & $7,543 \pm 45$ \\
\hline \multirow[t]{3}{*}{ OS-35838 } & ODP 1015B, 003H 04W, 55-57 cm & 16.85 & $\begin{array}{c}\text { Neogloboquadrina } \\
\text { pachyderma }\end{array}$ & & $9,130 \pm 50$ & 800 & $8,330 \pm 50$ & $9,209 \pm 50$ \\
\hline & & $22.48^{3}$ & Planktic foraminifera & & & & $10,095 \pm 135$ & \\
\hline & & $32.24^{3}$ & Planktic foraminifera & & & & $12,525 \pm 670$ & \\
\hline \multirow[t]{2}{*}{ OS-35839 } & ODP 1015B, 006H 03W, 112-114 cm & 44.36 & Uvigerina sp. & & $15,950 \pm 60$ & 1,750 & $14,200 \pm 60$ & $16,910 \pm 60$ \\
\hline & & $56.49^{3}$ & Planktic foraminifera & & & & $117,930 \pm 340$ & \\
\hline \multirow[t]{2}{*}{ OS-35840 } & ODP 1015B, 008H 03W, 105-107 cm & 63.35 & Uvigerina sp. & & $21,300 \pm 95$ & 1,750 & $19,550 \pm 95$ & $23,060 \pm 95$ \\
\hline & & $73.65^{3}$ & Planktic foraminifera & & & & $21,755 \pm 325$ & \\
\hline OS-39189 & ODP 1015B, 011H, 01W, 14-16cm & 87.95 & Mixed benthics & -0.92 & $29,700 \pm 150$ & 1,750 & $27,950 \pm 150$ & \\
\hline OS-39190 & ODP 1015B, 012H, CCW, 28-30cm & 97.59 & Mixed benthics & -1.15 & $33,500 \pm 220$ & 1,750 & $31,750 \pm 220$ & \\
\hline
\end{tabular}

${ }^{1}$ Ages were calibrated using a reservoir age of 1,750 years for the benthic assemblages as well as for mollusks and 800 and 1,100 years for the planktic foraminiferal samples of less than, and older than, 12,000 radiocarbon years, respectively (following Mix and others, 1999; Southon and others, 1990; Kienast and McKay, 2001).

${ }^{2}$ Calendar ages were calculated using Radiocarbon Calibration Program Revision 4.3 (CALIB 4.3) from Quaternary Isotope Lab, University of Washington based on Stuiver and Reimer (1998).

${ }^{3}$ Unpublished ODP radiocarbon ages (from Behl, oral communication, 1999). 
Signals were filtered at 800 to $6,000 \mathrm{~Hz}$ and recorded at a 0.25 -sec sweep. The data were recorded on magneto-optical disc for later processing as well as on a stable medium using an EPC recorder. Survey speeds of about $7 \mathrm{~km} / \mathrm{hr}$ provide a variable shot spacing between 1.5 and $2.5 \mathrm{~m}$ for the deep-tow boomer profiles.

\section{Selection of coring sites}

The coring program conducted in 1998 was part of a major effort to study sediment accumulation and the effects of anthropogenic sediment sources (for example, pollutants) in Santa Monica Bay (Alexander and Venherm, 2003). USGS cruise A-2-98-SC over the basin slope was devoted to box coring in upper slope and shelf areas of Santa Monica Bay (see station information at http://walrus.wr.usgs.gov/infobank/ a/a298sc/html/a-2-98-sc.meta.html). As a result, there was only limited ship time for piston-core operations. Six sites on the mid-slope area of the basin margin were adjacent to fold and fault structures that appeared to have recent movement, on the basis of boomer seismic-reflection profiles (fig. 2B). This study is based on radiocarbon dating of sediment from ODP Site 1015 and the six piston cores obtained in 1998.

\section{AMS radiocarbon dating}

Sediment ages for the six Santa Monica Bay cores were determined by accelerator mass spectrometry (AMS) ${ }^{14} \mathrm{C}$, using foraminifera and a mollusk (table 1). Because the highest degree of precision possible by AMS dating was not necessary to answer the questions posed in this study, we chose not to use mono-specific planktic foraminiferal samples for age-dating. Instead, the most abundant foraminiferal species in each sample were utilized. As a result, three radiocarbon dates were determined using the benthic species Uvigerina peregrina or Gyroidina altiformis, nine samples with the genera Uvigerina or Cibicides, and five samples using a mixed benthic foraminiferal assemblage. Two samples used planktic foraminifera, including one with Neogloboquadrina pachyderma and another with a mixed planktic foraminiferal assemblage. In addition, one gastropod was dated in core 361P1. A reservoir age of 1,750 years was chosen for the benthic foraminiferal samples following Mix and others (1999), and similarly applied to the gastropod because it occupied the same substrate as the benthic foraminifera. An 800-year reservoir age was used for the planktic foraminiferal samples because the radiocarbon ages of these samples were younger than 12,000 years (Southon and others, 1990, and Kienast and McKay, 2001). The CALIB 4.3 program (Stuiver and others, 1998) was used to calculate calendar ages from these radiocarbon ages.

Foraminifera were also used to date eleven samples from ODP Hole 1015B. Ten of these used benthic foraminifera, including five samples with Uvigerina, and five of a mixed benthic assemblage. One other sample is based on the planktic foraminifera N. pachyderma. As with the Santa Monica Bay cores, reservoir ages applied to these samples were 1,750 years for the benthic assemblages and 800 years for the planktics (following Mix and others, 1999; Southon and others, 1990; Kienast and McKay, 2001). Calendar years were again calculated by the CALIB 4.3 program (Stuiver and others, 1998).

We also report four previously unpublished radiocarbon ages on planktic foraminifera obtained by Per Bodén (Department of Geology and Geochemistry, Stockholm University, Sweden) as part of the original ODP investigations. Reservoir ages of 800 and 1,100 years were applied to the planktic foraminiferal samples of less than, and older than, 12,000 radiocarbon years, respectively (Southon and others, 1990; Kienast and McKay, 2001). These radiocarbon dates were converted to calendar years using the CALIB 4.3 program (Stuiver and others, 1998).

\section{Data}

The results of the radiocarbon dating are presented in table 1. In addition, the stratigraphic relations of the dates are shown for each core in figures 6 through 11 . The geologic setting for each core is discussed and, for the USGS piston cores, the physical properties logs and whole core photograph are also provided.

\section{ODP Site 1015}

The primary objective for radiocarbon dating the sediment sequence at Site 1015 was to provide age control for the high resolution sequence stratigraphy developed for Santa Monica Basin (Piper and others, 1999). ODP Site 1015 is located on the flat-lying basin plain at the southeastern end of Santa Monica Basin in water just deeper than $910 \mathrm{~m}$ (figs. 1 and 2). The basin plain is underlain by flat-lying turbidite deposits that onlap sediment on the flank of Redondo Knoll to the south (fig. 3). To the north, the stratigraphic section penetrated at Site 1015 pinches out and onlaps the northern margin of the basin. In the section below reflector $\mathrm{C}$, which is the deepest key reflector reached at the drill site, evidence for gas accumulation is indicated by the VAMP-like structure about $2 \mathrm{~km}$ south of Site 1015 (fig. 3). Other seismic-reflection profiles in the vicinity of ODP 1015 show additional evidence for gas accumulation at shallow depth in the basin fill (see site survey data in Lyle, 1995). Further, $20 \mathrm{~km}$ northeast of the drill site, methane hydrate was recovered from the crest of a mud volcano (Normark and others, 2003). Monitoring of gas composition during drilling showed no evidence for thermogenic sources (Shipboard Scientific Party, 1997).

High-resolution deep-tow boomer profiles across the ODP Site show that the upper $60 \mathrm{~m}$ of basin-plain deposits have very low relief locally and gradually thin northward 


\section{A-1-98-SC Core 361P1}

Boomer profile

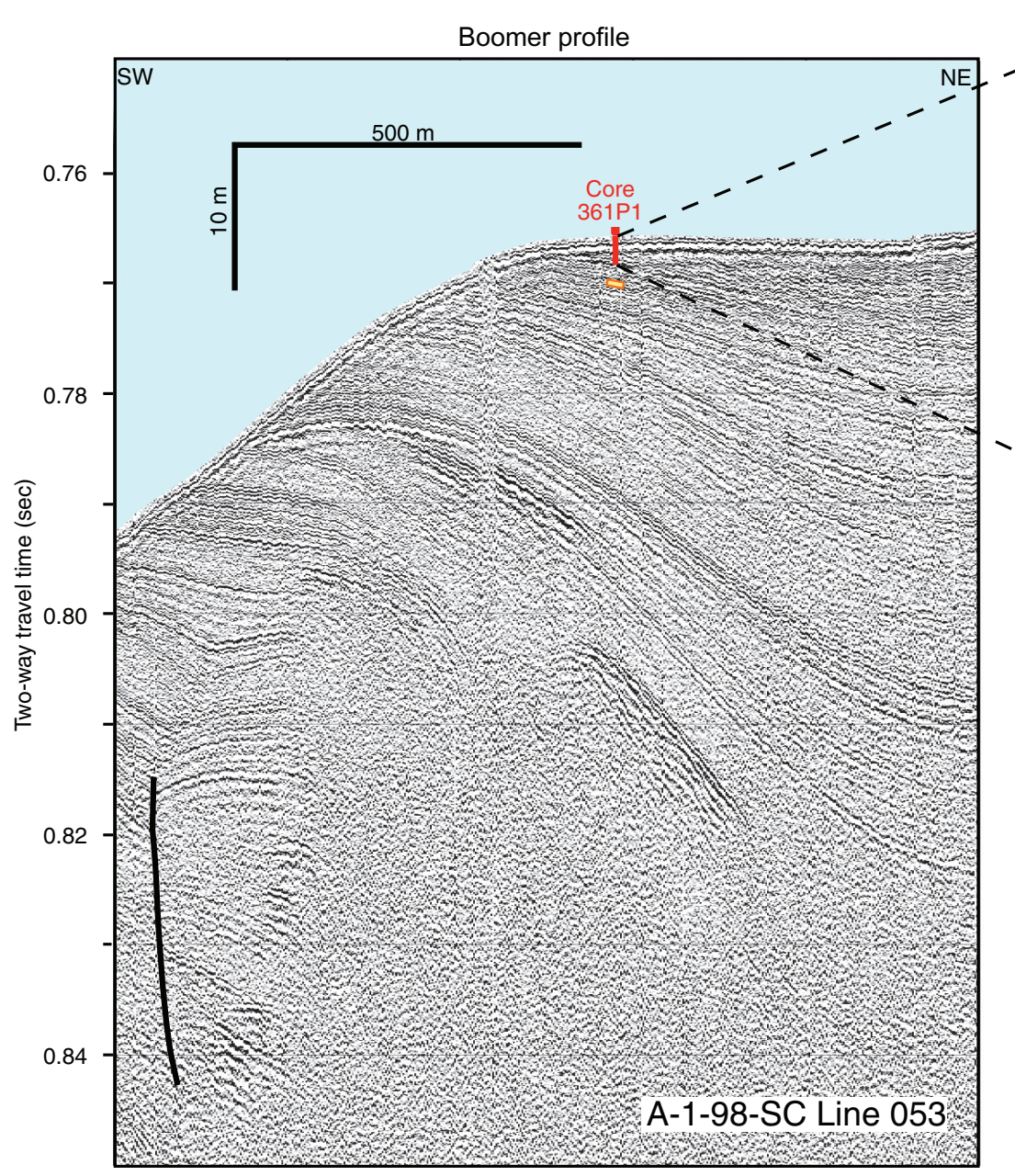

Sediment

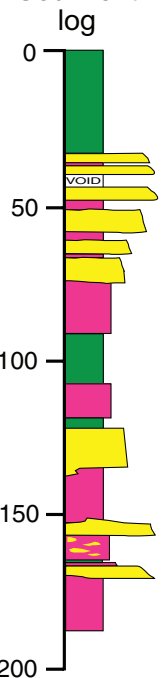

(dates in yr B.P.)

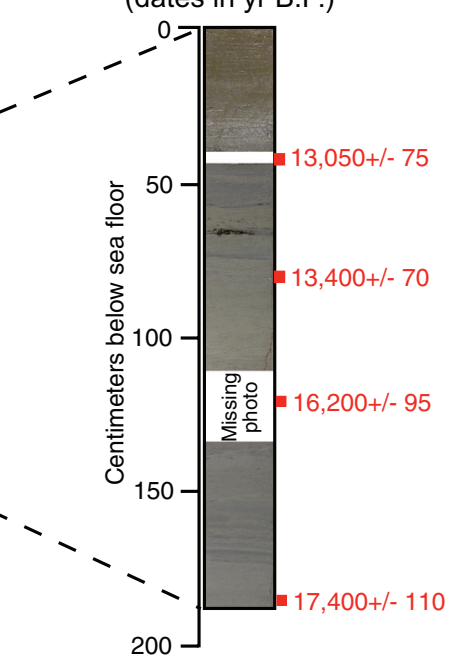

200
Physical Property Logs

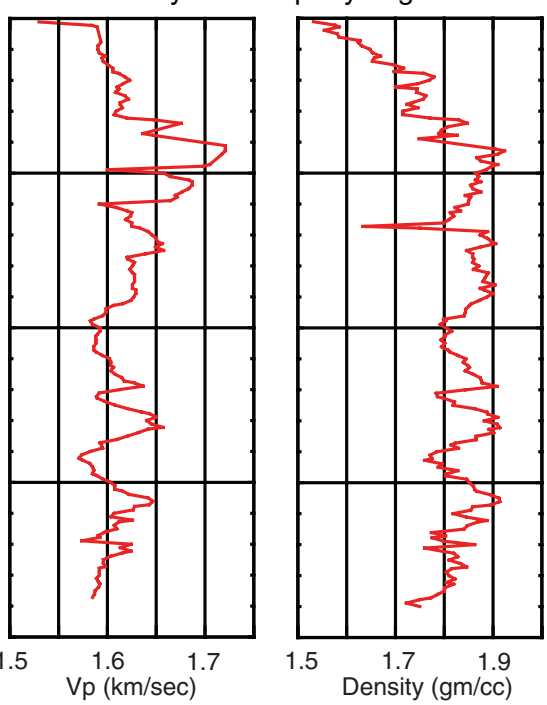

\section{Core depths in centimeter \\ $\square$ Hemipelagic mud \\ $\square$ Turbidite mud \\ $\square$ Sand}

Figure 6. Graphical sediment log for core 361P1 taken during cruise A-2-98-SC. To the left of the sediment log is the deep-tow boomer profile used for siting the core and a whole-core photograph with radiocarbon dates. Bold black line in boomer profile shows buried high-angle fault. The physical-properties logs, P-wave velocity (Vp) and gamma-ray density, are shown to the right. The target depth is shown by the orange-rimmed yellow rectangle. 


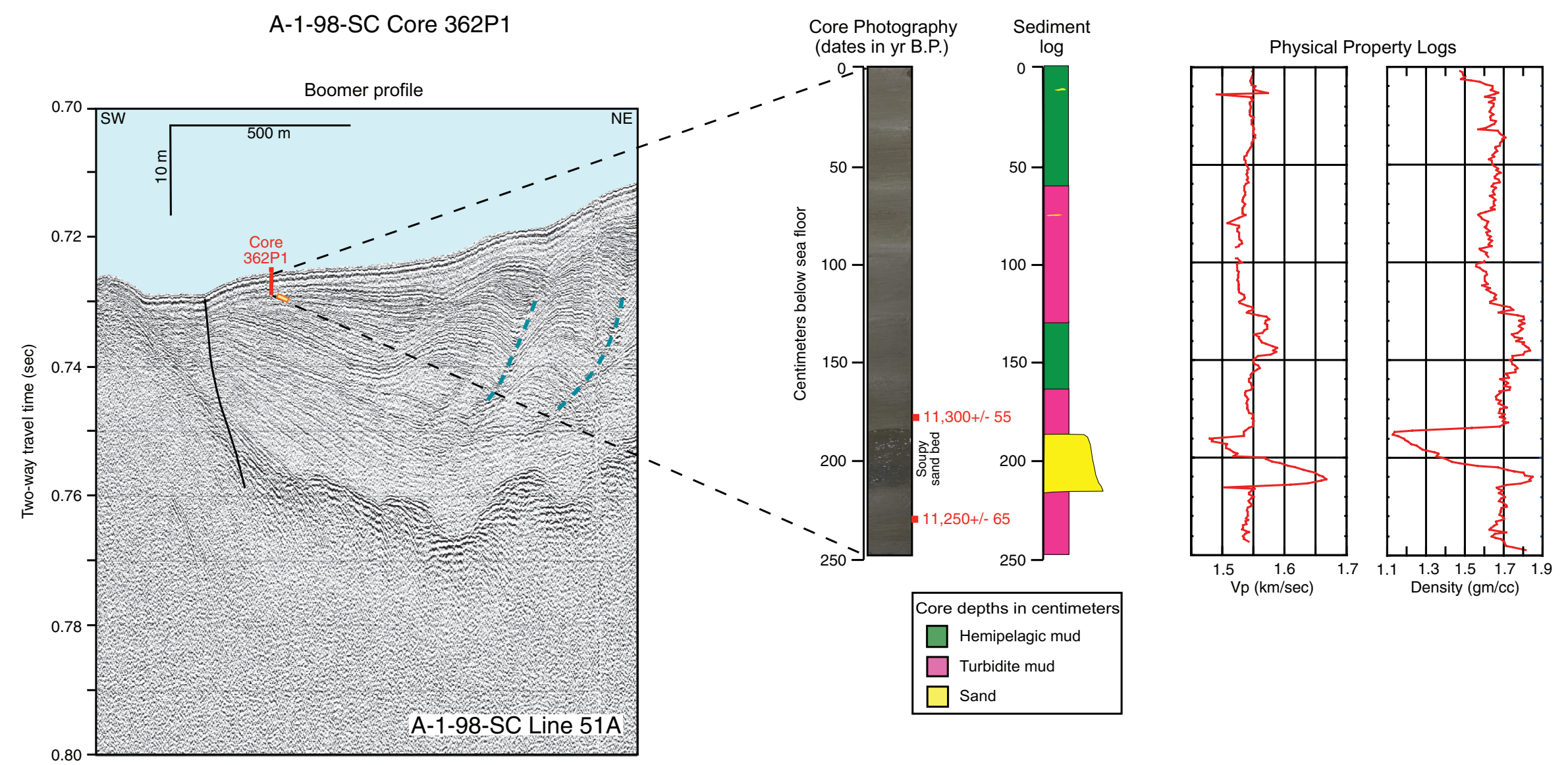

Figure 7. Graphical sediment log for core 362P1 taken during cruise A-2-98-SC. To the left of the sediment log is the deep-tow boomer profile used for siting the core and a whole-core photograph with radiocarbon dates. The physical-properties logs, P-wave velocity (Vp) and gamma-ray density, are shown to the right. Bold black line in boomer profile shows buried fault. The southwest-dipping dashed blue lines denote possible back-rotated slump blocks although their internal bedding is consistent with sediment-wave deposition from currents overflowing from Santa Monica Canyon (see fig. $2 B$ ). The target horizon is shown by the orange-rimmed yellow rectangle. 

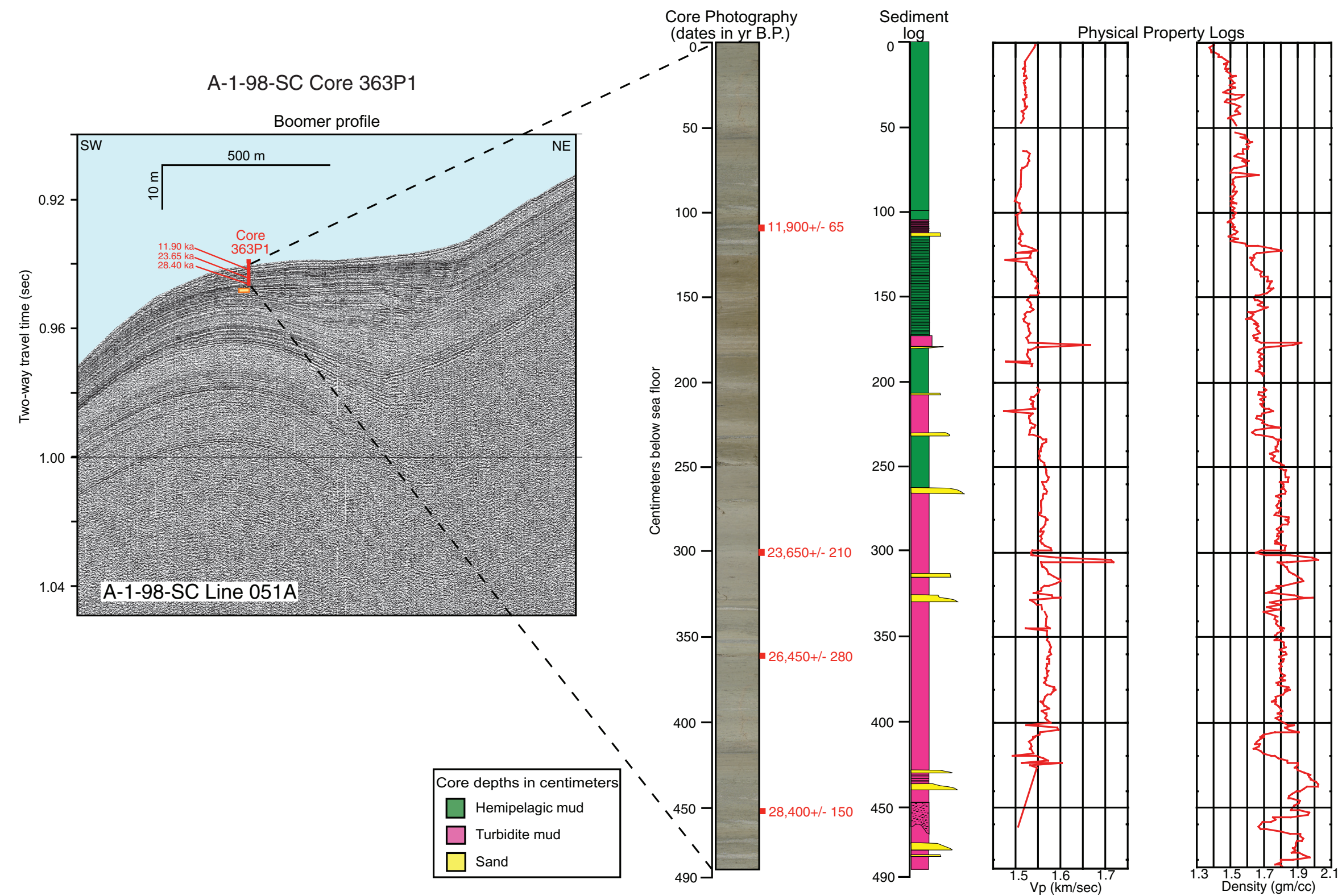

Figure 8. Graphical sediment log for core 363P1 taken during cruise A-2-98-SC. To the left of the sediment log is the deep-tow boomer profile used for siting the core and a whole-core photograph with radiocarbon dates. The physical-properties logs, P-wave velocity (Vp) and gamma-ray density, are shown to the right. The target depth is shown by the orange-rimmed yellow rectangle. 

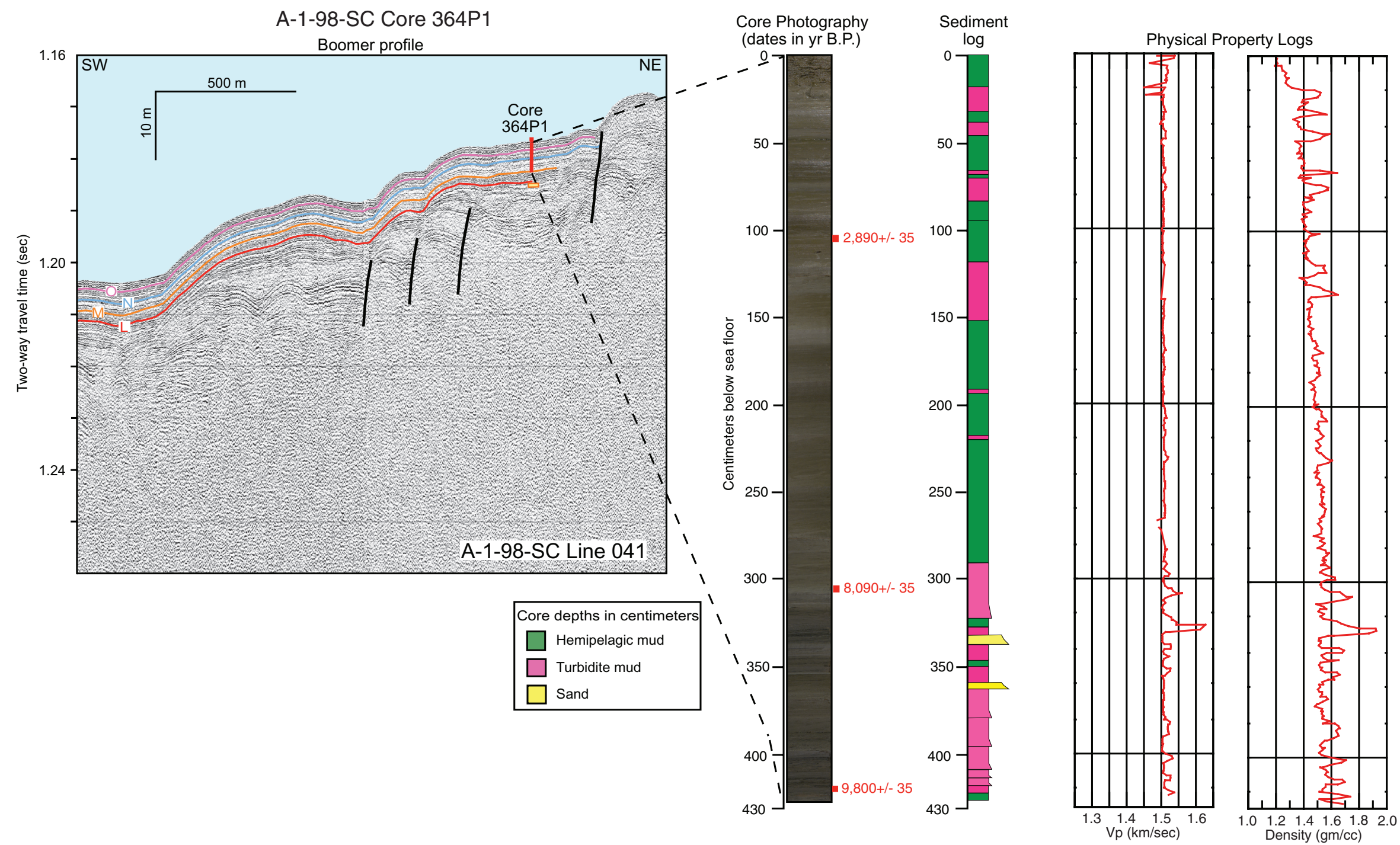

Figure 9. Graphical sediment log for core 364P1 taken during cruise A-2-98-SC. To the left of the sediment log is the deep-tow boomer profile used for siting the core and a whole-core photograph with radiocarbon dates. The physical-properties logs, P-wave velocity (Vp) and gamma-ray density, are shown to the right. Bold black lines in boomer profile show possible buried faults; sea floor offsets have been smoothed by draping of sediment starting just before key reflector $L$ was deposited. The target depth is shown by the orange-rimmed yellow rectangle. 

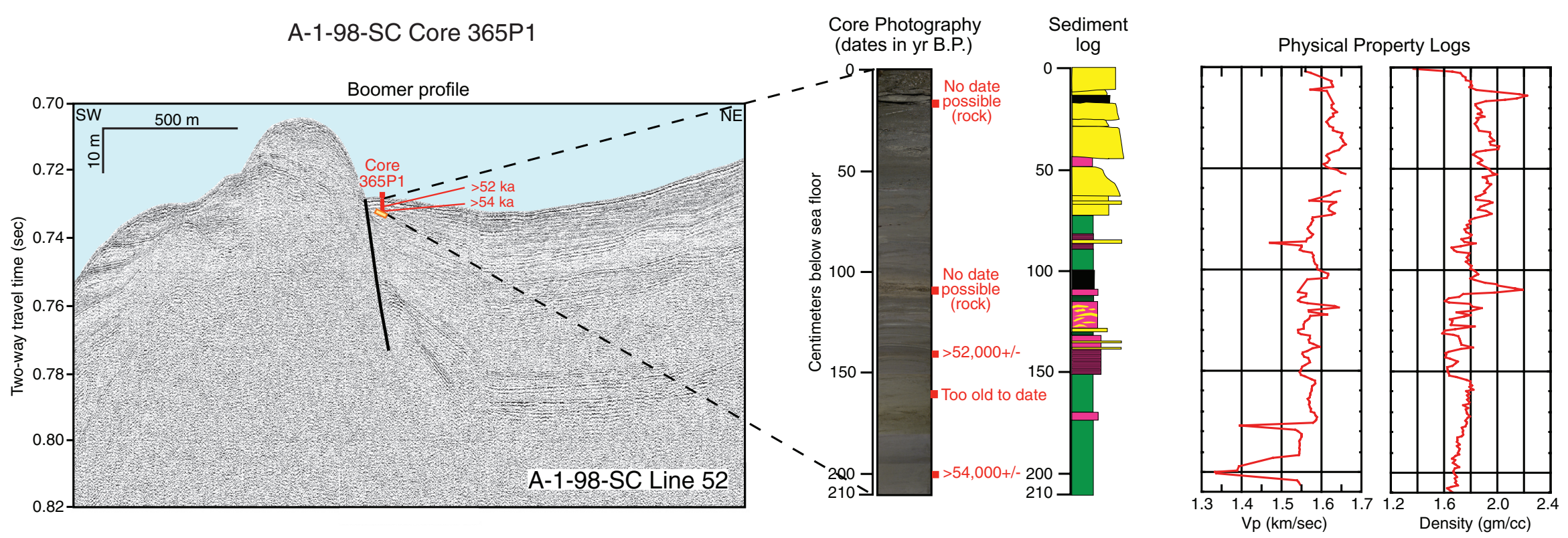

\begin{tabular}{|l}
\hline Core depths in centimeters \\
$\square$ Hemipelagic mud \\
$\square$ Turbidite mud \\
$\square$ Sand \\
$\square$ Sedimentary rock
\end{tabular}

Figure 10. Graphical sediment log for core 365P1 taken during cruise A-2-98-SC. To the left of the sediment log is the deep-tow boomer profile used for siting the core and a whole-core photograph with radiocarbon dates. The physical-properties logs, P-wave velocity (Vp) and gamma-ray density, are shown to the right. The older age of the samples at this site suggests that the sediment is talus from the faulted anticlinal fold immediately southwest. Bold black line in boomer profile shows buried fault. The top of the north-dipping section, which was the target horizon, is shown by the orange-rimmed yellow rectangle. 


\section{A-1-98-SC Core 366P1}

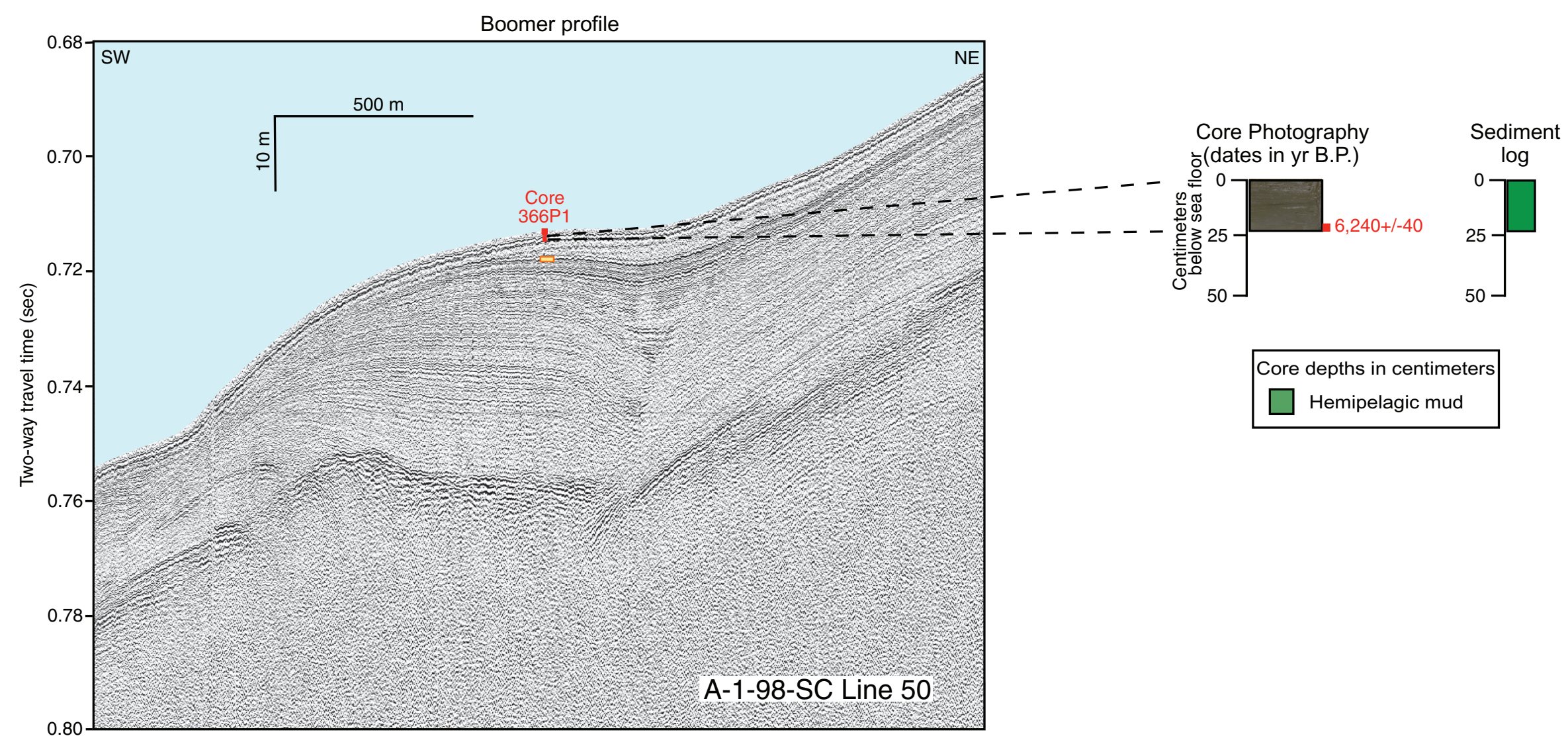

Figure 11. Graphical sediment log for core 366P1 taken during cruise A-2-98-SC. To the left of the sediment log is the deep-tow boomer profile used for siting the core and a whole-core photograph with radiocarbon dates. The target horizon is shown by the orange-rimmed yellow rectangle. 
toward the basin (fig. 4). The bulk of the sediment in the upper part of Santa Monica Basin was derived from the Hueneme Canyon area at the west end of the basin (Normark and others, 1998; Piper and others, 1999; Piper and Normark, 2001). The acoustic character of the reflections in this area is typical of that for ponded basin turbidite facies (Piper and others, 1999).

Two holes were drilled at the ODP site in Santa Monica Basin; Hole 1015A reached 149.5 meters below the sea floor (mbsf) and Hole B bottomed at 97.8 mbsf (Shipboard Scientific Party, 1997). The sediment log (fig. 5) is based on the Visual Core Description (VCD) forms used by the Leg 167 sedimentologists. Although core recovery exceeded 90 percent at Hole 1015A, some intervals were disturbed sufficiently that the sediment log constructed for this site is a composite of both holes. The log intervals from 32 to 40 mbsf, 56 to $63 \mathrm{mbsf}, 74$ to $79 \mathrm{mbsf}$, and 91 to $97 \mathrm{mbsf}$ are based on Hole 1015A; otherwise, the VCDs for Hole 1015B are used. The sediment log depicts only the upper $100 \mathrm{~m}$ at this site because we were unable to find datable material deeper in 1015A. All samples obtained for radiocarbon dating under this study were taken from Hole 1015B.

Beds in the upper $100 \mathrm{~m}$ of sediment cored in the basin plain are dominantly silt or sand ( $\sim 70$ percent). Two muddier intervals with generally thinner sand beds occur between 7 and 16 mbsf and 52 and 84 mbsf (fig. 5). The lower $50 \mathrm{~m}$ cored in Hole 1015A is mostly sand, which contributed to the problem of finding datable carbonate. The average sediment accumulation rate at the ODP site is about $3 \mathrm{~mm} / \mathrm{y}$, and this rate holds even after sea-level rise during the Holocene.

\section{Core site 361P}

Core station 361 is located at the northwestern end of a fold ridge on the mid-slope, adjacent to a narrow pass that leads to the deeper basin floor (figs. $2 B$ and 6). The goal was to date the upper part of a sequence of well-bedded sediment that appears to be faulted and uplifted to form a bench on the slope (fig. $2 B$ ). The core is less than $2 \mathrm{~m}$ in length, however, and thus it failed to reach the primary objective, which was a dipping horizon at about 6 mbsf. During the short interval of the latest Pleistocene that was sampled, deposition of sand beds was common but only muddy sediment represents the Holocene.

Four intervals from this core were dated (fig. 6 and table 1). The shallowest dated interval is from a whole-round sample that was taken for geotechnical studies. The sediment remaining after the geotechnical evaluation was sieved for foraminifera for dating. Assuming that the core recovered the mudline (that is, the water/sediment interface), the Holocene accumulation rate is less than $0.03 \mathrm{~mm} / \mathrm{y}$, which is two orders of magnitude less than on the basin floor. The latest Pleistocene rate for the underlying sand-rich interval is 0.33 $\mathrm{mm} / \mathrm{yr}$.

\section{Core site 362P}

Core station $362 \mathrm{P}$ is north of a fold ridge on the mid-slope where a layer of acoustically transparent sediment wedges out and overlies a northward-dipping section of sediment. The acoustic character of this wedge suggests turbidite deposits (figs. 2B and 7; see Piper and others, 1999). The turbidite section appears truncated and is unconformably overlain by the sediment drape. The objective for coring at this site was to sample the truncated and tilted turbidite sequence. The core sampled a graded sand bed at $2 \mathrm{~m}$ depth, confirming that the tilted turbidite section was reached by the core.

Both dated intervals in core $362 \mathrm{P} 1$ are basically from the Pleistocene-Holocene boundary and are effectively the same age, within the radiocarbon-age error limits (fig. 7 and table 1). The two dates bracket a graded sand bed tending to confirm that turbidite deposition can be considered instantaneous with respect to geologic time. The Holocene accumulation rate for the mud above the sand bed is $0.16 \mathrm{~mm} / \mathrm{yr}$.

\section{Core site 363P}

Core station 363P is sited on the same deep-tow boomer profile as for $362 \mathrm{P}$ but is about $150-\mathrm{m}$ deeper water depth than core site $362 \mathrm{P}$ (figs. $2 B$ and 8 ). The site was selected to sample the top of a gently folded section of well-bedded sediment. The folded section is overlain by a horizontal sequence that is ponded on the northeast side of the fold but thins abruptly on the basinward (southwest) limb of the underlying fold. The core is nearly $5 \mathrm{~m}$ in length but might not have sampled the shallowest reflector that is associated with the fold structure.

The well-bedded unit ponded behind the fold consists of thin sand and silt beds and turbidite mud. The coarser beds tend to thin and fine upwards, and the shallowest silt bed is just below the Pleistocene-Holocene boundary (fig. 8 and table 1). Only mud is deposited above this silty bed, and the Holocene accumulation rate is about $0.095 \mathrm{~mm} / \mathrm{yr}$. The deposits with sand and silt beds was deposited during marine oxygen isotope Stage 2 (Martinson and others, 1987) at a rate of 0.21 $\mathrm{mm} / \mathrm{yr}$. The age of the beds at the bottom of the core suggests that the fold was essentially in its present form by about $30 \mathrm{ka}$.

\section{Core site 364P}

Core station 364P is from the lower slope of the north side of Santa Monica Basin, about $40 \mathrm{~m}$ above the basin plain (figs. $2 B$ and 9). This site was selected to sample the bedded sequence in which key reflectors from $\mathrm{L}$ to $\mathrm{O}$ can be traced continuously through deep-tow boomer profiles from ODP 1015 (see tracklines in fig. 1). On the basin floor, the interval above reflector L consists of numerous thin- to thick-bedded sand units; hemipelagic mud beds are more common in the 
interval from 6 to $16 \mathrm{mbsf}$ (fig. 5). Core 34P1 recovered more than four meters of sediment and confirmed that turbidity currents are able to deposit sediment well above the floor of the basin. Similar to the correlative sequence in ODP 1015, the middle part of the core consists of mostly hemipelagic mud; graded silty mud and fine sand beds are common in the section below 3 mbsf in core $364 \mathrm{P} 1$.

Three radiocarbon dates from this core show the entire core is Holocene in age (fig. 9 and table 1). The sediment accumulation rate is $0.43 \mathrm{~mm} / \mathrm{yr}$, which is the highest for any of our cores from the continental slope.

\section{Core site 365P}

Core station 365P is north of a folded and fault-bounded ridge on the mid-slope. Similar to the setting for core site $362 \mathrm{P}$, there is a layer of sediment that wedges out to the southwest (toward the ridge) and unconformably overlies a northeast-dipping section of relatively well-layered sediment (figs. $2 B$ and 10). The northeast-dipping section under the unconformity appears truncated at or near the base of the uplifted ridge. The objective for coring at this site was to sample the truncated and tilted sequence.

The core sampled just over two meters of sediment with medium to thick-bedded sand in the upper $70 \mathrm{~cm}$. Indurated sediment (rock) was penetrated at two levels, and our attempts to date the sequence only determined that the sediment is older than $50 \mathrm{ka}$ (fig. 10 and table 1). The older dates and the presence of sedimentary rock fragments within the core suggest that much of the cored material may be debris from the fault scarp bounding the north side of the uplifted ridge. The core apparently did not penetrate deeply enough to sample the northeastdipping sedimentary section, the objective for this site.

\section{Core site 366P}

Core station 366P is on a mid-slope bench near the Santa Monica Canyon (figs. 2B and 11). The objective at this site was to penetrate the toe of an acoustically transparent sediment drape that pinches out southwestward across the margin of the mid-slope bench. The key-reflector sequence defined for the Santa Monica Basin floor indicates that most of the sediment filling the basin during the late Quaternary has come from the west end of the basin (Normark and others, 1998).

Santa Monica Canyon does not appear to be a major pathway for sediment transport (Piper and others, 1999). The acoustically transparent drape is thought to be Holocene hemipelagic mud overlying well-layered sediment that might be overbank deposition from Santa Monica Canyon.

The core obtained was too short to address the objectives at this site, and no physical property logs were attempted because of its short length. The mud recovered is late Holocene (fig. 11 and table 1), but the Holocene accumulation rate is less than $0.04 \mathrm{~mm} / \mathrm{yr}$, assuming that the core recovered the water/sediment interface. Because the transparent layer is just over $2 \mathrm{~m}$ thick at the target site, the base of the layer would be nearly $60 \mathrm{ka}$, which is unlikely. It seems probable that the piston core did not sample the sediment-water interface at the sea floor and the radiocarbon date represents some interval deeper in the transparent layer.

\section{Discussion}

The high-resolution seismic-stratigraphy defined for the Santa Monica Basin floor and the base-of-slope areas can be combined with the radiocarbon chronology for ODP Site 1015 to date movement on faults and landslides (figs. 5 and 12). In addition, these data can be used to help construct a sediment budget for the late Quaternary using the results of previous work in the Santa Monica Bay area (see for example, Alexander and Venherm, 2003; Sommerfield and Lee, 2003, 2004).

The deep-tow boomer profiles in figure 12 are taken from data collected by the Geological Survey of Canada. These data highlight examples that are chosen to show the utility of a basin-wide chronostratigraphy for Santa Monica Basin, should new high-resolution reflection profiles be collected to extend the seismic-hazard analysis farther seaward. An example of a buried landslide on the northern flank of Redondo Knoll is from an area between boomer profiles collected by the USGS (figs. 1 and 12A). The small landslide came to rest on a surface that is about $3 \mathrm{~m}$ above reflector $\mathrm{J}$ (measured along the left-hand side of fig. 12A). The slide mass is onlapped by a reflector that is about three meters below reflector $\mathrm{K}$, which in turn onlaps the highest part of the slide mass. Thus, the failure event probably occurred about $12 \mathrm{ka}$ (fig. 5).

The second example is from the western margin of the basin that falls outside the work area of the USGS earthquake hazard task (figs. 1 and $12 B$ and $C$ ). A major fault marks the southwestern margin of Santa Monica Basin at the base of the Santa Cruz-Catalina Ridge. The structure in this part of the basin remains poorly defined, however, and the fault shown in figure $12 B$ lies within the basin sediment fill, east of the main fault trace along the Santa Cruz-Catalina Ridge. Locally, narrow depressions have formed over this fault suggesting transtension in this area (figs. 1 and 12B). The youngest deformed reflection surface lies just below key reflector $\mathrm{O}$; sedimentation above reflector $\mathrm{O}$ has resulted in a gradual filling of the depression above the fault. As seen from figure 5 , the time of the most recent offset is approximately $2 \mathrm{ka}$. In contrast, the deeper penetration sleeve-gun profile in figure $12 C$ defines a steeply dipping fault that cuts the surface of a shallow anticlinal structure, thus suggesting transpression along the fault. The northeastern flank of the anticline is onlapped by key reflectors B to J, which show little evidence for penecontemporaneous folding. The growth of the anticlinal structure thus predates the oldest sediment dated in this study and might be as old as $90 \mathrm{ka}$ (see key reflector ages in Normark and others, 1998). When the change from transpression to transtension occurred on this structure is not 
determined with available data except to be sometime post reflector $\mathrm{J}$ (fig. 12C).

Although the usefulness of the chronostratigraphic control provided by radiocarbon dating of samples from ODP Site 1015 is easy to demonstrate, the effectiveness of short, conventional piston cores is more problematic. In general, the limited depth of sampling as a result of coring malfunction or the core hitting hard (including unconsolidated sand) substrate limits the overall success rate. For example, stations 361P, $363 \mathrm{P}$, and $366 \mathrm{P}$ did not provide constraints on the timing of deformation (figs. 6, 8, and 11). Core 362P1 was successful in confirming that the sediment drape was Holocene in age but did not sample to a sufficiently great depth to provide an age for the tilted and truncated section, which may be pre-Holocene in age (fig. 7). Core 365P1 provided no age control for the folding or faulting, but the age of the sediment recovered ( $>50 \mathrm{ka}$ ) suggests that older sediment is exposed and being shed from the adjacent uplifted ridge (fig. 10).

Core 364P1 was the most successful of the wire-line piston cores attempted for this study. This core confirmed that the stratigraphy from the well-dated ODP Site 1015 could be locally extended onto the lower slope (fig. 9). Thus, it should be possible to date offsets on structures adjacent to the basin floor. It has also been thought that rates of uplift of basin sediment might be used to determine strain on Borderland faults (Normark and Piper, 1998; Fisher and others, 2003). Although this approach has some applicability, caution must be used because the significance of Core 364P1 is that it shows that silt and sand beds from turbidity currents are being deposited on the lower slopes of the basin a minimum of $40 \mathrm{~m}$ above the basin floor. Intervals of thick sands on the basin floor have correlative fine-grained turbidites on the basin margins, whereas intervals with only thin sands on the basin floor lack identifiable turbidites (compare the sediment logs in figs. 5 and 9). The thicker turbidity currents such as those that deposited sand $40 \mathrm{~m}$ above the basin floor at 364P1 probably deposit silt and mud as much as 50 to $100 \mathrm{~m}$ above the basin floor. It is important to remember that the same key reflector beds observed to extend to core site 364P1 are also found on the overbank area of the Hueneme fan valley at comparable elevations above the channel floor. Apparently elevated or dipping sections of turbidite beds that are found above the basin floor are, therefore, not necessarily the result of tectonism.

Sommerfield and Lee (2004) showed that sediment-accumulation rates on the shelf and upper slope of Santa Monica Bay began to decrease between 12 and 9 ka after having been maximal ca. 15 to $10 \mathrm{ka}$, which they observed was after the interval of greatest sea-level lowering (ca. $18 \mathrm{ka}$ ). They argued that sea-level rise above the shelf break led to transgressive sedimentation on the shelf reducing sediment supply to the slope-basin area. The record documented by our new radiocarbon dates at ODP Site 1015, however, shows that there is limited correspondence between accumulation rates on the upper slope and shelf in Santa Monica Bay and that on the deep basin floor. For example, the maximum accumulation rate of about $4 \mathrm{~mm} / \mathrm{yr}$ on the basin floor lasted from 22 to $8 \mathrm{ka}$, thus encompassing both the last glacial maximum lowering and most of sea-level rise during the Holocene (fig. 5). Although the accumulation rate on the basin plain decreased to about 1 $\mathrm{mm} / \mathrm{yr}$ for about 4 millennia, by $4 \mathrm{ka}$, the accumulation rate was again high $(\sim 3 \mathrm{~mm} / \mathrm{yr})$. This indicates that sedimentation in the Santa Monica Bay area is not a reliable indicator of rates in the adjacent deep basin, in this case because the deltafed Hueneme Canyon (and not the much closer Santa Monica Canyon) is the dominant source for the deep basin.

\section{Conclusions}

This study presents 28 new radiocarbon dates for sediment from the Santa Monica Basin. The new radiocarbon dates include 17 from six piston cores on the northeastern margin of the basin and 11 from ODP Site 1015 on the basin floor. These dates provide an improved understanding of the changes in sediment supply to the basin as a result of sea-level rise from the late Pleistocene to current highstand condition. The study confirms a high sediment accumulation rate for the Santa Monica Basin floor, averaging more than $3.1 \mathrm{~mm} / \mathrm{yr}$ for the last $32 \mathrm{ka}$. During the marine oxygen-isotope Stage 2 lowstand, the sediment accumulation rate reached $4 \mathrm{~mm} / \mathrm{yr}$. Although the rates dropped to about $1 \mathrm{~mm} / \mathrm{yr}$ during the mid-Holocene, during the last few thousand years, the accumulation returned to about $3 \mathrm{~mm} / \mathrm{yr}$. The Hueneme Canyon at the west end of the basin remains the dominant sediment source even during highstand conditions. These new radiocarbon dates also provide chronologic control for a high-resolution basin-wide stratigraphic framework. Preliminary results using these dates show Holocene-age landslide and fault activity within the basin.

\section{Acknowledgments}

We thank the scientific staff and crew of USGS cruise A2-98-SC, especially B.D. Edwards and H.J. Lee, the co-chief scientists. Some of the samples for radiocarbon dating from ODP Site 1015 were prepared by S. Weir and T. Hundert of the Geological Survey of Canada (GSC). D. Brushett prepared the sediment $\log$ for the ODP site under the guidance of D.J.W. Piper, also of GSC. R. Sliter processed the deep-tow boomer profiles used for the core figures and C.E. Gutmacher provided corrected plots of core positions. The radiocarbon dates were provided by the National Ocean Sciences Accelerator Mass Spectrometry Facilities (NOSAMS) at the Woods Hole Oceanographic Institution. H.F. Ryan and M.A. Fisher provided critical reviews that improved the manuscript.

\section{References}

Alexander, C.R., and Venherm, C., 2003, Modern sedimentary processes in the Santa Monica, California continental 

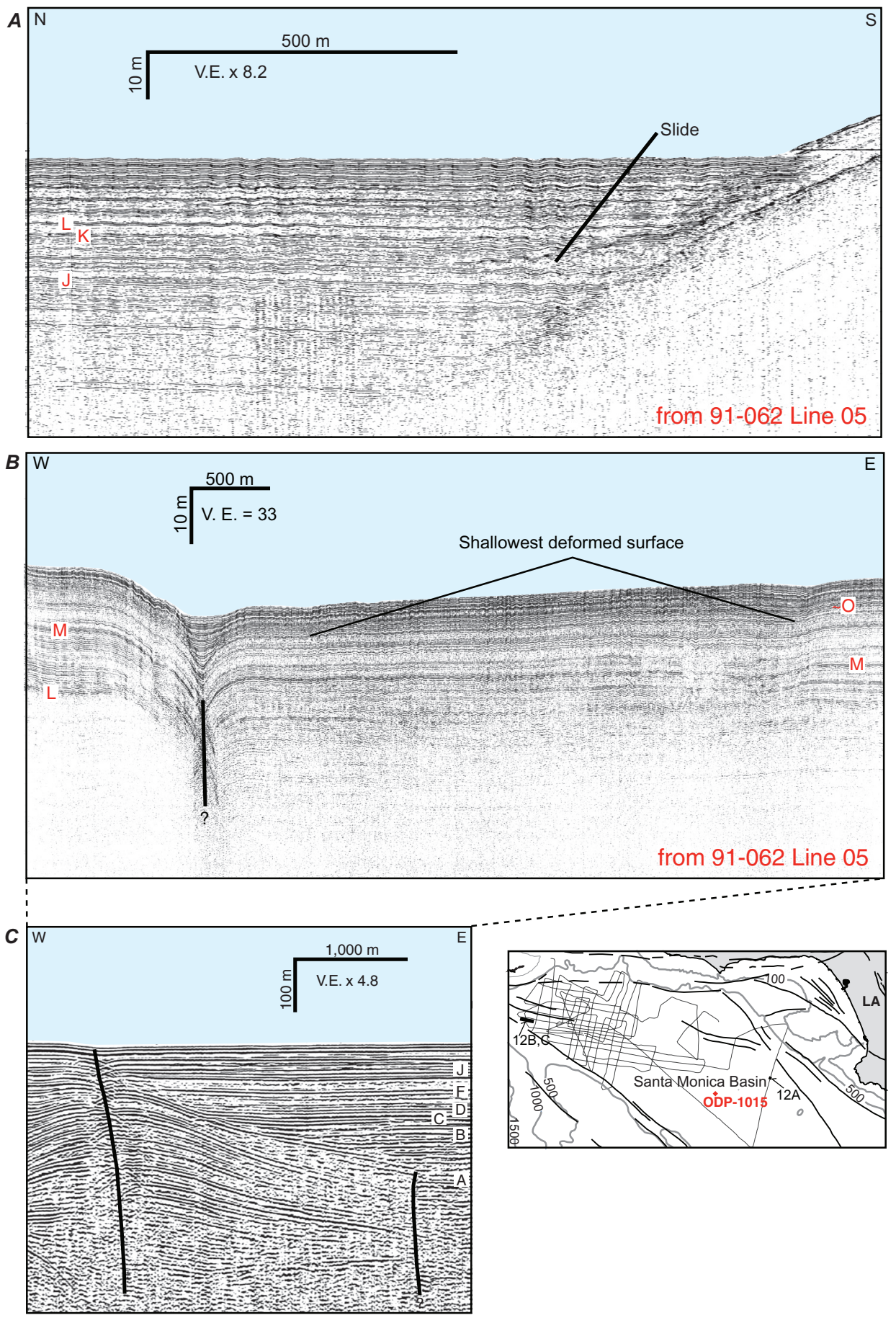

Figure 12. Along the lower slopes and floor of Santa Monica Basin mass wasting and fault offsets can be dated using a high-resolution boomer (Huntec) stratigraphy correlated with ODP Site 1015. See figures 1 and inset map above for location of profiles. $A$, In this example, the wedge-shaped landslide deposit is resting on a surface that is about $2 \mathrm{~m}$ above reflector $\mathrm{J}$. The top of the slide unit is completely covered by the time reflector $\mathrm{K}$ was deposited. The slide probably occurred about 11 or $12 \mathrm{ka}$. $B$, The youngest deformed surface over this basin margin fault is just below horizon 0 , or about $2 \mathrm{ka}$. Above this surface, sediment is draping the gently-sloping sea floor and gradually filling the depression along the fault. Below this surface, the thickness of the units is the same in the depression as it is on the margins of the depresession. $C$, This sleeve-gun profile shows the deeper structure related to the shallow features depicted in the Huntec profile in $B$. Deeper key reflectors are shown for reference. V.E., vertical exaggeration. LA, Los Angeles. 
margin — sediment accumulation, mixing and budget: Marine Environmental Research, v. 56, p. 177-204.

Crouch, J.K., and Suppe, J., 1993, Late Cenozoic tectonic evolution of the Los Angeles basin and inner California borderland - A model for core complex-like crustal extension: Geological Society of America Bulletin, v. 103, p. 1415-1434.

Dolan, J.F., Sieh, K. and Rockwell, T.K., 2000, Late Quaternary activity and seismic potential of the Santa Monica fault system, Los Angeles, California: Geological Society of America Bulletin, v. 112, p. 1559-1581.

Fisher, M.A., Normark, W.R., Bohannon, R.G., Sliter, R.W., and Calvert, A.J., 2003, Geology of the continental margin beneath Santa Monica Bay, Southern California, from seismic-reflection data: Bulletin Seismological Society of America, v. 93, p. 1955-1983.

Gardner, J.V., and Dartnell, P., 2002, Multibeam Mapping of the Los Angeles, California Margin: U.S. Geological Survey Open-File Report OF02-162.

Kienast, S.S., and McKay, J.L., 2001, Sea surface temperatures in the subarctic northeast Pacific reflect millennial-scale climate oscillations during the last 16 kyrs: Geophysical Research Letters, v. 28, p. 1563-1566.

Lee, H.J., and Weisberg, S.B., eds., 2003, Integrated assessment of an urban water body - Santa Monica Bay, California: Special Issue of Marine Environmental Research, v. 56, p. $1-341$.

Lyle, M., Gallaway, P., and Mix, A.C., 1995, W9406 and EW9504 Site Surveys of the California Margin Proposed Drilling Sites, Leg. 167: Boise State University, Idaho, Technical Report BSU CGISS 95-12.

Martinson, D.G., Pisias, N.G., Hays, J.D., Imbrie, J., Moore, T.C., Jr., and Shackleton, N.J., 1987. Age dating and the orbital theory of the ice ages: development of a high-resolution 0 to 300,000-year chronostratigraphy: Quaternary Research, v. 27, p. 1-29.

Mix, A.C., Lund, D.C., Pisias, N.G., and Bodén, P., 1999, Rapid climate oscillations in the northeast Pacific during the last deglaciation reflect Northern and Southern Hemisphere sources, in Clark, P., Webb, R.S., and Keigwin, L.D., eds., Mechanisms for Global Climate Change at Millennial Time Scales: Geophysical Monograph Series, American Geophysical Union, Washington, D.C., v. 112, p. 127-148.

Nardin, T.R, and Henyey, T.L., 1978, Pliocene-Pleistocene diastrophism of Santa Monica and San Pedro shelves, California continental borderland: American Association Petroleum Geologists Bulletin, v. 62, p.247-272.

NOAA, 1998, NOS Hydrographic Survey Data, U.S. Coastal Waters: Boulder, CO, World Data Center for Marine Geology and Geophysics, Data Announcement 00-MGG-05 (data available at http://www.ngdc.noaa.gov/mgg/fliers/00mgg05.html).

Normark, W.R., Hein, J.R., Powell, Charles L., II, Lorenson, T.D., Lee, H.J., and Edwards, B.D., 2003, Methane Hydrate Recovered From A Mud Volcano in Santa Monica Basin, Offshore Southern California: Eos Transactions American Geophysical Union, v. 84, no. 46, Fall Meeting Supplement,
Abstract OS51B-0855.

Normark, W.R., and Piper, D.J.W., 1998, Preliminary evaluation of recent movement on structures within the Santa Monica Basin, offshore southern California: U.S. Geological Survey Open-File Report No. 98-518, 60 p.

Normark, W.R., Piper, D.J.W., and Hiscott, R.N., 1998, Sea level controls on the textural characteristics and depositional architecture of the Hueneme and associated submarine fan systems, Santa Monica Basin, California: Sedimentology, v. 45, p. 53-70.

Piper, D.J.W., Hiscott, R.N., and Normark, W.R., 1999, Outcrop-scale acoustic facies analysis and latest Quaternary development of Hueneme and Dume submarine fans, offshore California: Sedimentology, v. 46, p. 47-78.

Piper, D.J.W., and Normark, W.R., 2001, Sandy fans-from Amazon to Hueneme and beyond: American Association of Petroleum Geologists Bulletin, v. 85, p. 1407-1438.

Piper, D.J.W., Normark, W.R., and McGann, M., 2003, Variations in accumulation rate of late Quaternary turbidite deposits in Santa Monica Basin, offshore southern California: Eos Transactions American Geophysical Union, v. 84, no. 46, Fall Meeting Supplement, Abstract OS52B-0916.

Scholl, D.W., and Cooper, A.K., 1978, VAMPs — possible hydrocarbon-bearing structures in Bering Sea Basin: American Association of Petroleum Geologists Bulletin, v. 62, p. 2481-2488.

Shipboard Scientific Party, 1997, Site 1015: Proceedings of the Ocean Drilling Program, Initial Reports, v.167, p. 223-237.

Sommerfield, C.K., and Lee, H.J., 2003, Magnitude and variability of Holocene sediment accumulation in Santa Monica Bay, California: Marine Environmental Research, v. 56, p. 151-176.

Sommerfield, C.K., and Lee, H.J., 2004, Cross-shelf sediment transport since the last glacial maximum, southern California margin: Geology, v. 32, p. 345-348.

Sorlien, C.C., 1999, Rapid subsidence and south propagation of the active Santa Monica Mountains-Channel Islands thrust, Annual Report Southern California Earthquake Center, 5 p. Available on line at: http://www.scec.org/research/ 99research

Sorlien, C.C., Broderick, K., Kamerling, M.J., Fisher, M.A., Normark, W.R., Sliter, R., and Seeber, L., 2003, Structure and kinematics beneath Santa Monica Bay, California: Pacific Section American Association Petroleum Geologists, May 2003, Conference Program and Abstracts, p. 90.

Southon, J.R., Nelson, D.E., and Vogel, J.S., 1990, A record of past ocean-atmosphere radiocarbon differences from the Northeast Pacific: Paleoceanography v. 5, p. 197-206.

Stuiver, M., Reimer, P.J., Bard, E., Beck, J.W., Burr, G.S., Hughen, K.A., Kromer, B., McCormac, F.G., Plicht, V.D.J., and Spurk, M., 1998, INTCAL98 radiocarbon age calibration 24,000-0 cal BP: Radiocarbon, v. 40, p. 1041-1083.

Warrick, J.A., and Milliman, J.D., 2003, Hyperpycnal sediment discharge from semiarid southern California rivers - Implications for coastal sediment budgets: Geology, v. 31, p. 781-784. 